\title{
原子力エネルギーの製鉄プロセスへの利用*
}

\section{On Application of Nuclear Energy to Iron Making Process}

\section{藤 木 俊 三**}

Shunzo FUJIKI

\section{1. 製鉄業における原子カエネルギー 利用の意義}

\section{$1 \cdot 1$ わが国製鉄技術の特色}

近年に打汸かが国鉄鋼業の発展は，世界史上類を見 ないもので, 粗鋼生産実績として 1960 年の 2200 万 $\mathrm{t}$, 1970 年における 9300 万 $\mathrm{t}$ の実績㹥 1 に示す海外主 要諸国の生産量推移と比較していちじるしい䀣隔を端的 に示すものである.

製鉄業に不可欠の主原料，エネルギー資源を国内にほ とんど持たないわが国のこのような異例の発展要因は， 巨大規模の高炉，LD 転炉，ストリップミルなどにわた る大臨海製鉄所を相ついで建設稼働させ，その主原料， エネルギー源を大型船により効率的に輸送し, また一貫 製鉄工程全般にわたり，その操業技術成績を極限に近く 追求してやまぬことにあつた。とくに前表に見られるよ うに，諸外国に比べて，製鋼工程における LD 転炉へ の移行をはるが早いテンボで推進したことは，わが国 鉄鋼業の国際競争力を強大ならしめた要因である. 高炉 溶銑を多量に消費するこのプロセスが，高炉技術の向上 と大型化に拍車をかけることになつた反面，必然的に高 炉用原料炭所要量の飛踓的增大を招来した。

表 1 鉄鋼生産内容の比較 （暦年）

$\times 10^{3} \mathrm{mt}$

\begin{tabular}{|c|c|c|c|c|c|c|}
\hline & & 1960 & 1965 & 1968 & 1969 & 1970 \\
\hline $\begin{array}{l}\text { 日 } \\
\text { 本 }\end{array}$ & $\begin{array}{l}\text { 銑 鉄 } \\
\text { 粗 鋼 } \\
\text { 内 } \mathrm{LD} \%\end{array}$ & $\begin{array}{rr}11 & 896 \\
22 & 138 \\
11 \cdot 9\end{array}$ & $\begin{array}{rr}27 & 502 \\
41 & 161 \\
& 55 \cdot 0\end{array}$ & $\begin{array}{r}46397 \\
66893 \\
73 \cdot 7\end{array}$ & $\begin{array}{rr}58 & 147 \\
82 & 166 \\
76 \cdot 9\end{array}$ & 94327 \\
\hline $\begin{array}{l}\text { 米 } \\
\text { 国 }\end{array}$ & $\begin{array}{l}\text { 粗 } \mathrm{O} \text { 鋼 } \\
\text { 内 } \%\end{array}$ & $\begin{array}{r}90068 \\
3 \cdot 4\end{array}$ & $\begin{array}{r}118985 \\
17 \cdot 4\end{array}$ & $\begin{array}{r}118932 \\
37 \cdot 1\end{array}$ & $\begin{array}{r}127977 \\
42 \cdot 7\end{array}$ & 119414 \\
\hline 举 & $\begin{array}{l}\text { 粗 鋼 } \\
\text { 内 } \mathrm{LD} \%\end{array}$ & $\begin{array}{rr}65 & 292 \\
& 3 \cdot 8\end{array}$ & $\begin{array}{rr}91 & 021 \\
& 4 \cdot 4\end{array}$ & $\begin{array}{r}106532 \\
10 \cdot 6\end{array}$ & 110291 & 116000 \\
\hline 西 & $\begin{array}{l}\text { 粗 鋼 } \\
\text { 内 } \mathrm{LD} \%\end{array}$ & $\begin{array}{r}34 \begin{array}{l}100 \\
2 \cdot 5\end{array}\end{array}$ & $\begin{array}{r}36821 \\
19 \cdot 1\end{array}$ & $\begin{array}{rr}41 & 159 \\
& 37 \cdot 1\end{array}$ & $\begin{array}{r}45 \quad 316 \\
46 \cdot 1\end{array}$ & 45042 \\
\hline
\end{tabular}

表 2 製造業のエネルギー消費構成比（1969）

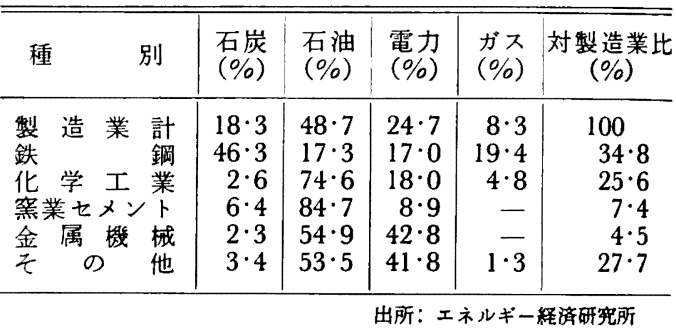

表 3 鉄鋼業における 1 次および副生エネルギー 消費実績 (1969)

\begin{tabular}{|c|c|c|c|c|}
\hline & 別 & 単 位 & 消 費 量 & $\begin{array}{l}\text { カ口リー } \\
\text { 比 }(\%)\end{array}$ \\
\hline $\begin{array}{l}1 \\
\text { 次 } \\
\simeq \\
\text { ネ } \\
\text { ル } \\
\text { ギ } \\
1\end{array}$ & 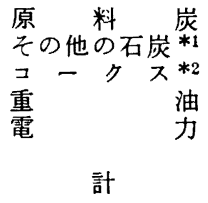 & $\begin{array}{c}10^{3} \mathrm{t} \\
\prime \prime \\
1 " \\
10^{3} \mathrm{k} l \\
10^{6} \mathrm{kWh} \\
10^{9} \mathrm{kcal}\end{array}$ & $\begin{array}{rl}25 & 034 \\
& 516 \\
17 & 583 \\
8 & 541 \\
34 & 876 \\
* 3(42 & 876) \\
487 & 506\end{array}$ & $\begin{array}{r}38 \cdot 5 \\
0 \cdot 7 \\
26 \cdot 0 \\
17 \cdot 3 \\
17 \cdot 5 \\
(21 \cdot 5) \\
100 \cdot 0\end{array}$ \\
\hline $\begin{array}{l}\text { 副ル } \\
\text { 生ギ } \\
\text { エ } \\
\text { ネ }\end{array}$ & 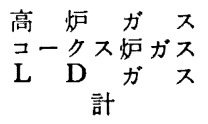 & $\begin{array}{c}10^{3} \mathrm{~m}^{3} \\
" 1 " \\
" 1\end{array}$ & $\begin{array}{rr}80 & 595 \\
8 & 710 \\
3 & 372\end{array}$ & $\begin{array}{r}13 \cdot 2 \\
8 \cdot 6 \\
1 \cdot 5 \\
23 \cdot 3\end{array}$ \\
\hline \multicolumn{2}{|c|}{$\begin{array}{l}\text { 粗鋼 } \mathrm{t} \text { 当り1次エネル } \\
\text { ギー }\end{array}$} & $10^{3} \mathrm{kcal}$ & 5601 & \\
\hline $\begin{array}{l}* 1 \\
* 2 \\
* 3\end{array}$ & 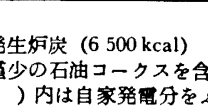 & 炭 & $\begin{array}{l}\text { 出所：通産 } \\
\text { ccal) 無㖶炭 }\end{array}$ & $\begin{array}{l}\text { 旨定統計 } \\
7000 \text { kcal) }\end{array}$ \\
\hline
\end{tabular}

\section{2 鉄鋼業におけるエネルギー使用実態}

最近の産業界全般にわたる生産規模の拡大と，立地上 の高密度化の急速な 進展は, 環境対策の課題をふくめ て, エネルギー問題を, 全産業に共通な深刻な問題とし てクローズアップしつつある. 1970 年代は，このエネ ルギー問題を中心に, 激動の 10 年間として展開し,

* 昭和46年 3 月 30 日受付

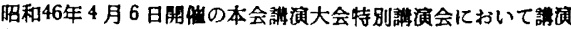

** 共同研究会原子力部会银 


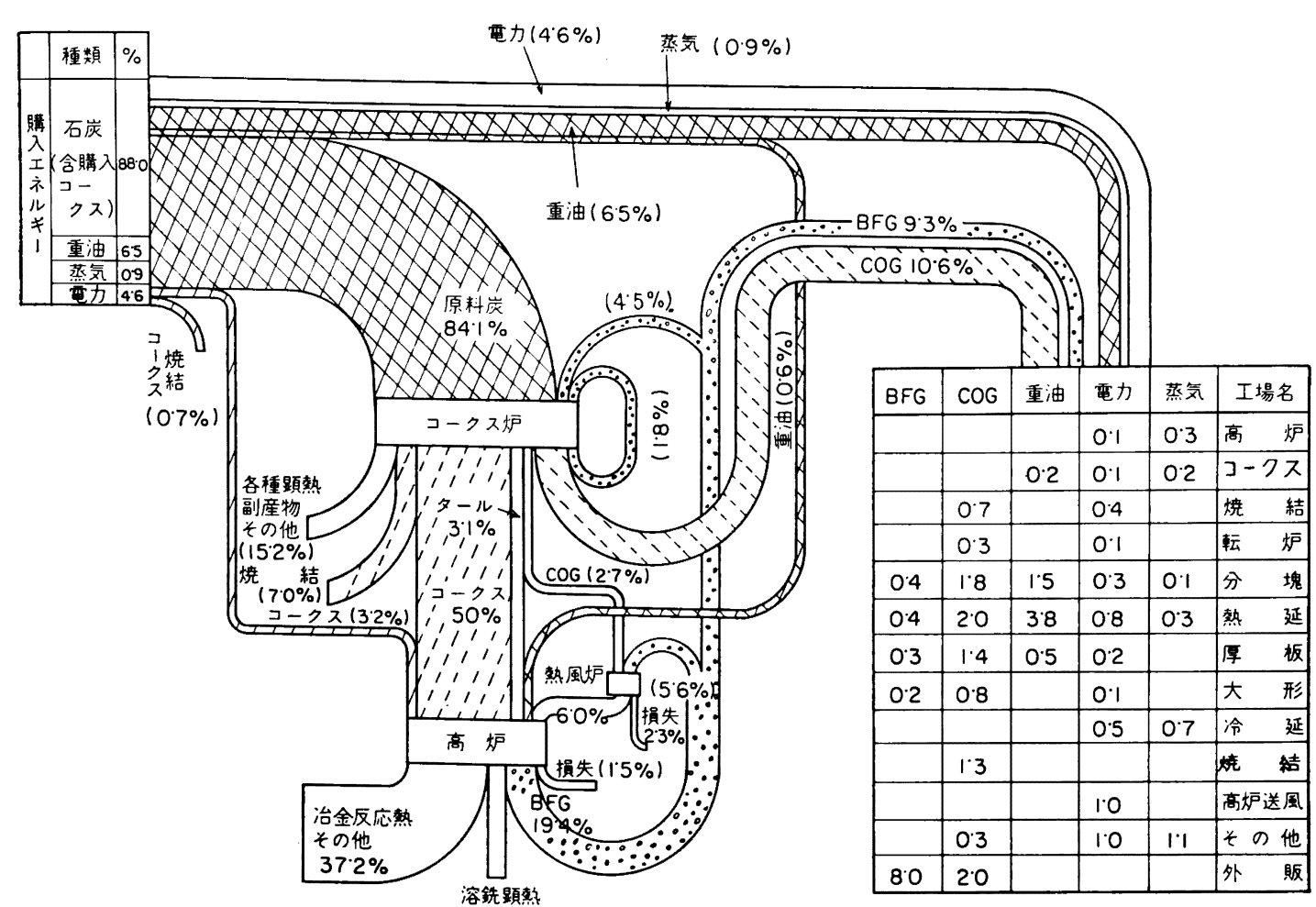

$(4.8 \%)$

困 1 一貫製鉄所のエネルギーバランスの例

一出所：熱経済技術部会 S45 資料一

1980. 年代に持ち越されること注必至であろう。

表 2 にわが国全産業におけるエネルギー消費の内容を 一括したが，周知のように，鉄鋼業はエネルギーの最多 消費産業であり，したがつてエネルギー動向に対して深 い関心を抱くものである. 表 3 にうが国鉄鋼業における 1 次及び副生エネルギー消費実繥を掲げた. 1 次エネル ギー中，原料炭に由来するものは，コークスの形態での 購入分をあわせ，カロリーベースで約 $65 \%$ を占める. ただしこの数值は高炉を持たない特殊鋼, 電炉メ一カー などをもふくめた総括的な実績值である．次に一貫製鉄 所（原料炭からのコークス化を行なう）におけるエネル ギーバランスの平均的な一例を図 1 に示した。製鉄所の 全工程を総合して，購入エネルギーの中で，原料炭は $80 \%$ 以上の质倒的高率を占めることがわかる，圧延加 熱部門などにおいて, 原料炭に由来する副生ガス (COG, BFG）を使用する部門も多く，現行の一貫製鉄方式にあ つては，原料炭は，単に高炉部門のみでなく，全製鉄所 内の主要なエネルギー源として，いかに重きをなしてい るかが認識されよう。

\section{3 原料炭の使用実態}

前節のごとき製鉄用主力エネルギー源である原料炭汢 表 4 に見られるごとく，わが国は海外諸国に比べてその
表 4 原料炭の輸入依存度の比較

\begin{tabular}{|c|c|c|c|c|}
\hline \multirow{2}{*}{ 国 別 } & \multirow{2}{*}{ 年 度 } & \multicolumn{3}{|c|}{ 原 料 炭 内 訳 } \\
\hline & & 国内 $\times 10^{3} \mathrm{t}$ & 輸入 $\times 10^{3} \mathrm{t}$ & 輸入比 \% \\
\hline 日 本 & $\begin{array}{r}1968 \\
70 \\
75\end{array}$ & $\begin{array}{ll}9 & 495 \\
8 & 500 \\
6 & 000\end{array}$ & $\begin{array}{ll}27 & 652 \\
46 & 900 \\
92 & 800\end{array}$ & $\begin{array}{l}74 \\
84 \\
94\end{array}$ \\
\hline 米国 & $\begin{array}{r}1968 \\
70 \\
75\end{array}$ & $\begin{array}{ll}73 & 700 \\
74 & 400 \\
75 & 800\end{array}$ & $\bar{\square}$ & $\begin{array}{l}0 \\
0 \\
0\end{array}$ \\
\hline EEC & $\begin{array}{r}1968 \\
70 \\
75\end{array}$ & $\begin{array}{ll}64 & 800 \\
60 & 000 \\
59 & 200\end{array}$ & $\begin{array}{ll}12 & 000 \\
16 & 000 \\
22 & 000\end{array}$ & $\begin{array}{l}16 \\
21 \\
27\end{array}$ \\
\hline
\end{tabular}

[注] 1970 年……予定 1975 年……想定

輸入依存度が著しくたかく, 今後国内炭の調達量が減少 してゆくとされているので，この比率は逐年上昇するこ とになろう. この中, 高灯操業に不可欠の強粘結炭（現 状では原料炭使用量の $2 / 3$ を占める） は，完全に全量を 輸入に仰いでいる.このような逼迫した原料炭事情のさ 中にあつて, わが国鉄鋼業としては, 原料炭節減方策の 積極的な推進をはかり，成果は着実に挙りつつある. 従 来の標準コークス比 $500 \mathrm{~kg}$ に比べ, 重油吹込量の增加 
などの諸対策により最近では 350～400 kg 級の実績を 記録する高炉が多数ある.

原料炭は，今後に深刻な問題を残しているというもの の，世界的に見て，遠からぬ時期に，資源的に枯渴する という類のものではない。しかし世界的に偏在資源であ り, 産炭国, 採炭地域における労働事情㴔激に悪化し つつあること，炭鉱の新規開発には犮大な資金と，長期 間を要すること，また需給調達の実際面や，取得条件に おいて，完全に売手市場で需要者側の主体性をおりこみ がたいことなど，先行きその量的確保と取得価格の両面 から危機感を深めざるをえない.

\section{4 その他のエネルギー}

現行の製鉄方式にあつては，原料炭を除く他のエネル ギー源は，量的に副次的立場に位置付けされるが，原料 炭節減, 公害対策の推進などから重油 (とくに低硫黄系), 天然ガス，あるいは電力の量および使用範囲の拡大を考 虑しなければならない，最近の産油国を汭じめとする石 油業界の世界的動静法，単なる一時的現象とは見なしが たい重大性をはらんでいる. 天然ガスは公害対策の上か らも, 今後の需要の激増が予想され, 日本列島近傍から の新資源の開発には，石油とともに大きな期待が寄せら れている.しかし現実問題としては，LNG による海外 依存を建前とせざるを得ず，輸送と利用の実態から，海 外諸国と比較すると使用条件は著しく不利で，鉄鋼業を 初め, 産業界で単なる熱源として大量に消費するエネル ギーとしては大きな問題を残すものと見られる.

電力は, 最近やかましい環境対策の上からも, また使
用面における簡便性と合理性や，技術的にプロセスの近 代化や自動化に好適であることなど，一般用はもとよ り, 産業のエネルギー源としてのウェイト法加速度的に 増大するものと予測される. しかし現状の火力主体の発 電方式では, 公害, 立地問題に伴う設置上の障害や, 発 電の量，コスト両面から期待にそいがたい要素が多い.

\section{5 原子カエネルギーへの期待と鉄釗業}

原料炭を初め, 重油, 天然ガス, さらに現行発電方式 による電力にいたるまで, 個別に, 又共通にそれぞれ重大 な問題に直面している. かかる変化の多いエネルギー情 勢の中で, 原子力エネルギーの産業界への利用が漸く実 用開花期を迎えたことは，まことにその意義が大きい. 原子力エネルギー利用の歴史はきわめて浅いが, 技術進 展のテンポは異常に急速に行なわれており, 早くも原子 力発電は将来の発電の主導的役割を約束されている. 原 子力発電の今後が, 発電規模の大型化と, 他エネルギー の相対的なコスト上昇との関連で，量と価格の両面を満 足する方向をとるならば, 鉄鋼業にあつても溶解・加熱 エネルギー源として，その使用分野を大幅に拡大しうる 可能性がある.このように, 現実的に新しく登場した原 子力エネルギーの利用という問題に前向きの姿勢で取り 組むことは, 時代の趨勢と, エネルギー界の現実問題を 直視すれば当然のことというべきである. 国体然料の主 力時代から液体, 気体燃料への転換が行なわれてすでに 久しいが，今や「赤い火から白い火」への時代的転換を 促す技術開発に鉄鋼業も積極的に取り組む必要がある. 最近における高温ガス炉 ( $\mathrm{He} \cdot$ ガス冷却原子炉) の技術

表 5 海外における高温ガス师の開発状況

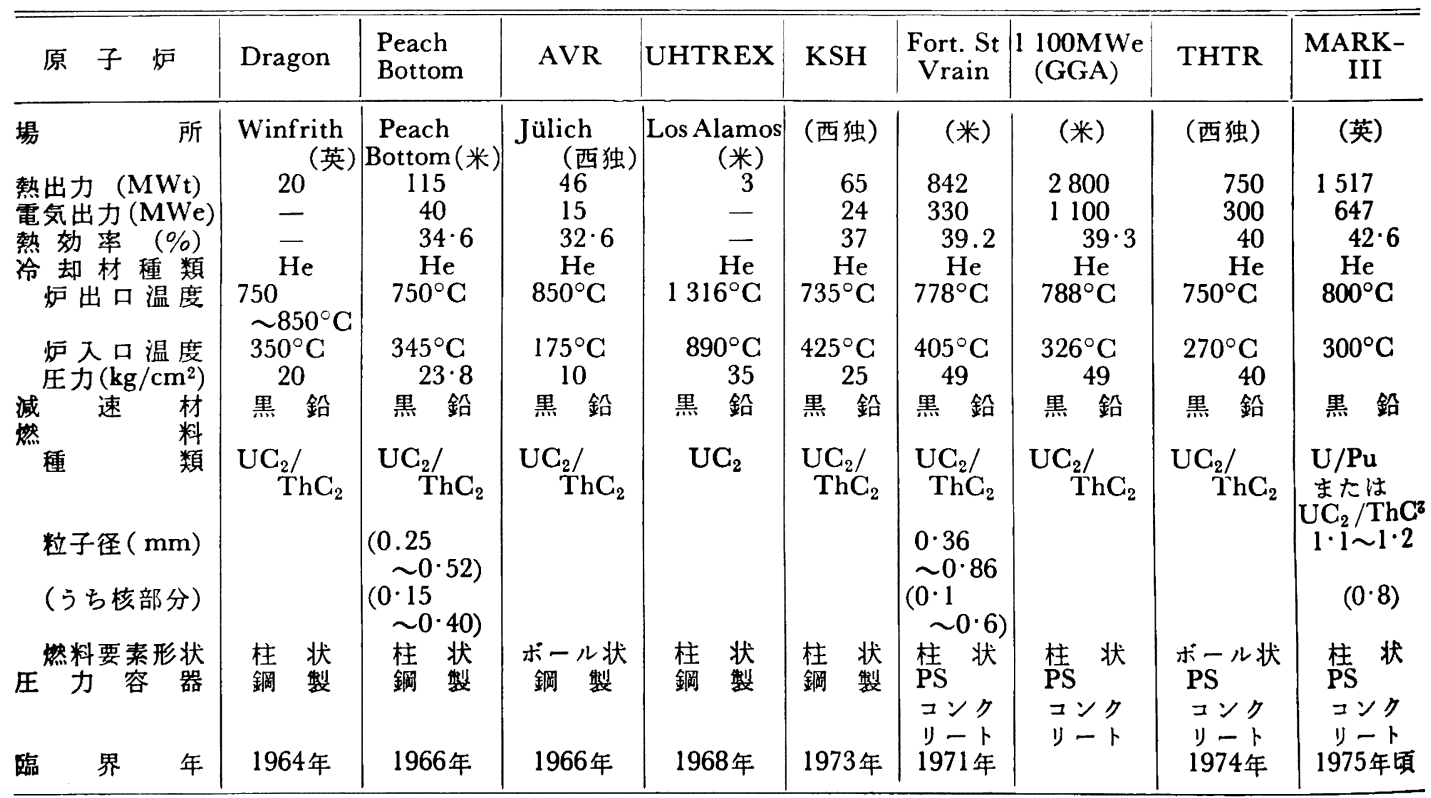


開発はきわめて急速に行なわれ，ことに核燃料の技術進 歩によつて, 抽出されうる $\mathrm{He}$ ガス温度は逐次上昇しつ つあり，これを $1000^{\circ} \mathrm{C}$ 程度にまで高めることにより熱 エネルギーをプロセスヒートとして直接利用することの 可能性を期待させるものである. 表 5 に海外における高 温ガス炉の開発状況を示した. 特殊実験炉のUHTREX 炉を除外すると, He ガス出口温度は, 現状において $850^{\circ} \mathrm{C}$ 程度までの開発はすでに完了したものと考えられ ている. 原子力エネルギーを熱及び電力の両形態で, 効 苴的に組み合わせ利用しようとするいわゆる原子力製鉄 の技術開発の構想は, このような背景の中から生れてき たものであり, 海外諸国に比較し, エネルギー事情の格 段に劣悪なわが国においてこそ顧虑すべき必要性が最も 大きいと考えられる・

このような観点から昭和 44 年 6 月 日本鉄鋼協会と 日本鉄鋼連盟は連名で「高温原子炉開発に関する要望 書」を政府に提出することにより，国の機関による実験 炉の開発およびその設置についての具体的施策を要望し たが，同時に原子力製鉄に関する技術的問題点などにつ いて日本鉄鋼協会原子力部会で検討を進めているもので ある・

\section{2. 原子力利用のあり方と技術的課題}

\section{1 原子力製鉄プロセスの概要}

$2 \cdot 1 \cdot 1$ 原子力製鉄システムの基本的方式

高温ガス炉のエネルギーを製鉄プロセスに導入利用す る原子力製鉄システムの標準基本方式として困 2 のパタ 一ンを採択する. これ以外にも原子力エネルギーの投入 分野として, 高炉への熱エネルギー利用, 電気製銑炉方 式としての原子力電力の集中投入なども考えられる. し

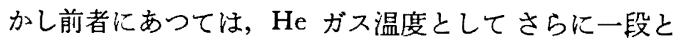
高温が要求されること, 原料炭の節減対策の範囲に止ま ること, また後者では電力のみの利用に近く, また現実 的に問題があることなどから, それぞれ, 比較対象のパ ターンとして考慮さるべきものと判断した. 上記基本方 式の場合は, 原子力エネルギーは, (1)高温部分を還元ガ スの製造, 改質および加熱用の熱エネルギーとして用 い, (2)ついで温度の下つた $\mathrm{He}$ ガス顕熱で発電を行な い電炉製鋼部門への利用分とするカスケード方式であ る.

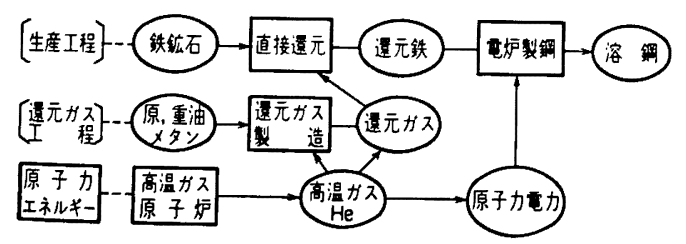

図 2 原子力製鉄・ブロセス・モデルパターン （直接製鉄一電炉製鋼）

\section{$2 \cdot 1 \cdot 2$ 原子炉出口のガス温度}

原子炉冷却材である $\mathrm{He}$ ガスの顕熱を利用する原子力 製鉄においては, He ガス出口温度, 熱交換方式, 還元 ガスおよび還元鉄製造方式等が相互に密接な関連を有す る.

（1）還元鉄製造における還元ガス所要温度

後述するごとく，原子力製鉄における還元鉄製造プロ セスとしては，シャフト炉，流動層の二方式が対象とさ れるが，前者では炉入口の還元ガス温度として 950〜 $1000^{\circ} \mathrm{C}$ が要望され, 最低限 $850^{\circ} \mathrm{C}$ は必要である. これ 以下の温度になると, 還元所要時間と還元度が低下す る. しかし $1000^{\circ} \mathrm{C}$ 以上では炉内装入鉱粒の融着現象 を起す危険性がある. 流動層法では，粒状鉱石を伐用 し，一般に多段式であるため還元層間における還元ガス への熱補給も可能で, シャフト炉に比べて還元カス入口 温度汁低目としてよい. H アイアン法注低温，F10R 法は高温の流動層法としての典型的な例であるが，低温 法で注生産性が低く，大規模な生産炉を目標とする場 合, 開発の対象としがたい. 高温流動層法こは, 還元ガ ス温度として 850 $900^{\circ} \mathrm{C}$ 注最低限必要である. 以上か ら熱交換器部分における $\mathrm{He}$ 一還元ガスの温度差を約 $150^{\circ} \mathrm{C}$ と想定すると, $\mathrm{He}$ ガス温度々して $1000^{\circ} \mathrm{C}$ 以上 が要求されることとなる.

（2）還元ガス製造プロセスにおける温度

現在すでに確立されている天然ガス（メタン）の水蒸 気改質法では, メタンと水蒸気を混合予熱の上, Ni 触媒 充填層中に通入し，管外からの間接加熱により分解改質 を行なわせるプロセスである，この場合の管の外壁温度 は 900 $1000^{\circ} \mathrm{C}$ に達する. 改質ガス中のメタン残量を 少なくする上からも高温が望まれる. 外熱を $\mathrm{He}$ ガス顕 熱により行なう場合は, $\mathrm{He}$ ガス温度は当然 $1000^{\circ} \mathrm{C}$ 程 度が要求される.さらに原油, 重油などを還元ガス源と し，これを熱媒体流動層方式などにより，全量ガス化す る新技術にあつては, $\mathrm{He}$ ガス温度はさらに高温 (1000 ${ }^{\circ} \mathrm{C}$ 以上）が好ましいとされる.

（3）耐熱金属材料の耐熱特性からの温度制約

以上から原子灲出口 $\mathrm{He}$ ガス温度として, $1000^{\circ} \mathrm{C}$ 以 上が望まれることが理解されるが，一方熱交換器をはじ め，原子炉内，ダクト部における金属材料の特性面から の制約を考慮に入れねばならない. $1000^{\circ} \mathrm{C}$ 以上の高温 環境下で，長期にわたり，所要特性を維持しうる超耐熱 金属材料の開発は現状では不十分である，現実問題とし て, $1000^{\circ} \mathrm{C}$ 程度までならば，現用の鉄ベーフ材（例 : Incoloy 800, HK 40), $\mathrm{Ni}$ ベース材 (例 : Inconel 600, HastelloyX) などの材料を使用し, 設計構造面からのバ ックアップと，使用期間に若干の制約を付すなどの弾力 的運用によつて 措置されることとなる. しふし，1000 ${ }^{\circ} \mathrm{C}$ 以上の温度領域では，一般金属材料の耐熱特性は急 激に低下し, また材料の成形, 溶接加工性, さらにコス 
卜問題など，現状では直ちに適切な対象材料が見当らな いというのが穾態である.したがって以上の 3 項目の条 件を総合し，現段階として注材料面からも He ガス出口 温度 $1000^{\circ} \mathrm{C}$ を目標上寸ることが妥当と見られる. さ らに実験原子炉以降の段階で泣当然 $1000^{c} \mathrm{C}$ 以上が実 現さるべく，原子师サイド，上くに材料開発面に強く期 待しなければならない。

\section{2 開発上の技術的課題（製鉄側）}

（1）還元ガス製造プロセス

鉄鉱石還元用として，資源的沉制約の少ない原料を対 象に, 原子力エネルギーを有効に利用し, 低廉な還元ガ スの量産に適したプロセスの開発が要請される. 天然ガ スやナフサからの還元ガス製造技術注，ほほ確立されて いるが，鉄鋼業で大量に使用する還元ガス源にこれらの 資源をもとめることは現実的に問題である.したがつ て，原油，重油を対象とするのが妥当と考えられ，また 原子力熱エネルギーの有効利用という立場から, 熱媒体 による流動層方式の開発を主に考える必要があろう。し かもこのガス化の際に, 同時に硫黄分の除去を能率的に 行なうごとき体系を付加しなければならない。

\section{(2) 鉄鉱石還元}

シャフト炉, 流動層炉両方式に対する最適操業の選択 之開発（還元ガスの組成, 温度, 供給方式などが操業上 に及ぼす影響など）が課題とされる。また設備技術面に おいて，とくに単位設備能力の大幅な引上げを目途とす る技術開発注最も重要である. 現在海外では原子力製鉄 と注無関係にこれらの技術の開発が行なわれているが， その開発実績注, 日産 500〜600 $\mathrm{t}$ 級で， $1000 \mathrm{t}$ 級がよ うやく計画段階にある現況である. このように現段階で 直接還元設備の規模は現存の高炉に比較して小さく, ま た還元ガス源である天然ガス等を容易に入手出来る地域 に立地している.したがつて近代的製鉄所の必須条件で ある量産, 高能率, 低コストを実現する上からも, 現状 の規模は開発の前段階の域を出ていないことを銘記すべ きである.

\section{（3）熱交換器の開発}

原子炉冷却材である $\mathrm{He}$ ガスの顕熱 $\left(1000^{\circ} \mathrm{C}\right.$ または それ以上）を効率よく，製鉄側に伝達熱交換を行なうに は, 適切な熱交換システムの開発を必要とする.これに は, (1) 適切な耐熱金属忉料の選択々開発, (2)直接熱交換 方式にあつては還元ガス中の $\mathrm{H}_{2}$ の $\mathrm{He}$ ガスループへの 透過対策技術の開発 ( $\mathrm{He}$ ガス中の $\mathrm{H}_{2}$ 含有許容限度量 の確定と, 洩入 $\mathrm{H}_{2}$ の除去技術の開発), (3)直接熱交換 方式に加元間接熱交換方式の併行検討 $\left(\mathrm{H}_{2}\right.$, 核分裂生成 物の漏洩対策としてその設計構造の研究, 中間媒体の選 択など), (4)大型熱交換器の設計, 製作に伴う問題点の 解決（形式および製造関係技術, 検査法の確立など）が 技術的課题とされる.

（4）電炉製鋼技術の開発
還元鉄を主配合とする高性能の UHP 電炉の技術と関 連設備面の開発. 還元鉄の輸送貯蔵, 取扱上の問題点の 解明など.

(5) その他

(1)原子炉, 製鉄工程直結儿伴う安全問題対策, (2) He ガスサイクル中におけるエネルギーの効率的使用配分に 関するトータルシステムの研究, (3)原子力製鉄の経済性 の検討なども重要な課题である.

\section{3. 日本鉄鋼協会原子力部会の活動状況}

\section{1 原子力部会の組織と運営}

高温原子炉のエネルギーを鉄鋼製造工程に熱エネルギ 一として直接導入し, 化石燃料の節減を図り, とくに原 料炭問題解決への有力手段と考元，またわが国将来の重 要なエネルギー源として開発の必要性について旧入幡製 鉄株式会社副社長故湯川正夫氏が提唱され，これは日本 鉄鋼協会昭和 43 年 4 月の理事会に扩いて協議のうえ, 研究の具体化をはかることとなつた。

原子力製鉄の技術開発汇関する研究は，その性格上， 日本鉄鋼協会における共同の場で運営されることが適切 であるとの判断の上に立ち, 昭和 43 年 9 月, 原子力部 会が設立され，湯川氏が初代部会長に委嘱された。原子 カエネルギーを製鉄工程に利用する上においての大きな 課題である「原子力発電による電力の利用」および「原 子力熱エネルギーの製鉄工程への直接利用」に関し調查 検討すべく，また製鉄用原子炉の検討をも対象として， 当初, 第 1 第 3 小委員会が設置された. その後の検討 経過と, 研究活動の進展に伴い, 現在は, 以上の 3 小委 員会に加えて, 熱交換器を担当する第 4 小委員会, 還元 ガス製造検討を対象として第 5 小委員会, 更に製鉄プロ セスパターンの設定, サブシステムの開発手順など総合 的汇企画するシステム小委員会が設置された. また害験 担当の小委員会として，45 年度シャフト炉小委員会が, また昭和 46 年度共同実験を対象とし，本年 2 月熱交換 器小委員会と還元ガス小委員会の発足を見た. 図 3 に現 在の鉄鋼協会原子力部会の組織内容を示した.

\section{2 部会としての技術体系の検討}

原子力部会活動の全般に関連し, 検討の前提とすべき 数項目についてふれておこう.

（1）原子力製鉄基本方式の設定（前出）.

(2) 原子炉出口 $\mathrm{He}$ ガス温度 $(2 \cdot 1 \cdot 2$ 参照) 計画中 の実駼炉段階では $1000^{\circ} \mathrm{C}$ を目標とし, それ以降の段 階で，原子炉側と製鉄側，とくに金属材料の開発により $1000^{\circ} \mathrm{C}$ 以上を目指す. $1000 \sim 1200^{\circ} \mathrm{C}$ の間での引き上 げ可能な温度幅の想定は今後行なう。

(3) サブシステムの技術項目

(1)還元プロセス—シャフト炉, 流動層炉の両方式を 併行して検討の対象とするが, 開発実験のステップとし ては，実績の多いシャフト帄を先行させる. 


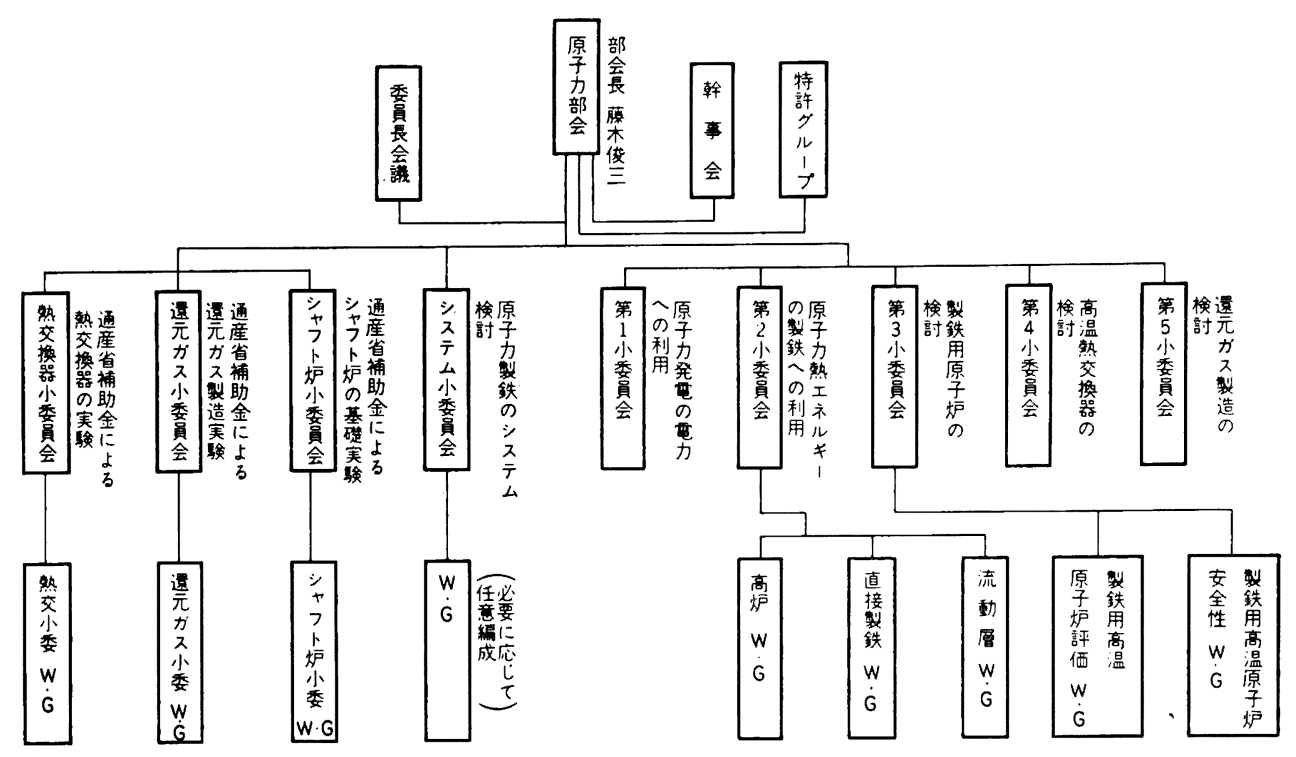

図 3 日本鉄鋼協会原子力部会組織（昭和 46 年 3 月 31 日現在）

(2)邉元ガスの性状と取扱い——゙ス成分としては， $\mathrm{H}_{2}$ および $\mathrm{H}_{2}+\mathrm{CO}$ の両系統を対象とする. 循環システム の取扱いからは $\mathrm{H}_{2}$ 系統がすぐれているが， $\mathrm{H}_{2}+\mathrm{CO}$ 系 には $\mathrm{CO}$ による熱補償のメリットがある。 $\mathrm{H}_{2}, \mathrm{CO}$ 以 外の不純成分総量は当面 5\% 以下を目標とする. 還元炉 からの排ガスは完全循環再使用を建前とする．これは原 子力製鉄システムのエネルギー有効利用の根幹をなすべ きものである.

(3)還元ガス製造——ガス源として前述のごとく原油, 重油（とくに重質油）を対象とし、メタンなどは比較対 象物として取り扱う。還元ガス製造には原子力熱エネル ギーの有効利用を第一義とする.

(5)熱交換器関係一原子力製鉄技術開発上のキーポイ ントに当たるサブシステムとして，部会としても特に重 点的開発項目とする. 熱交換方式として直接換熱式と間 接換熱方式（後出）の二者択一は今後の課題とし, 双方 の検討を併行させるが，とくに当面直接熱交の場合の問 題点の解明と開発 ( $\mathrm{H}_{2}$ 除去対策, $\mathrm{H}_{2}$ の炕心構造材への 影響度の確認など）に重点をおく，また間接熱交型の媒 体としてはスチーム，Heおよび溶融メタルとしての Pb を重点的に検討する.

(5)トータルシステムにおけるマテリアルおよびエネル ギーバランスの検討一一原子力製鉄のトータルシステム におけるエネルギー配分上効率の高い体系を研究する. 原子炬出入口の $\mathrm{He}$ ガス温度として $1000^{\circ} \mathrm{C}$ および 400 ${ }^{\circ} \mathrm{C}$, プロセスヒートとしての $\mathrm{He}$ ガス利用範囲 $1000^{\circ} \mathrm{C}$ $\sim 750^{\circ} \mathrm{C}$, また $\mathrm{He}$ ガス循環システム中には水蒸気発生, 発電部門を挿入してエネルギーバランスの効率化をはか る.

\section{3 原子力部会第 1 小委員会関係 (原子力発電による 電力の利用)}

第 1 小委員会は将来の製鉄所への原子力発電の導入を 想定し，(1) 原子力発電による電力の現行製鉄工程への 適用，（2）電力の利用による製鉄工程改善について，主 として経済的観点からその導入の可能性につき検討を加 えている.検討対象としての製鉄所規模を粗鋼年産 1000 万トンの生産能力を有するモデルプラントとし，その主 要設備内容は表 6 に示するのを想定した.

3.3 .1 原子力発電による電力の現在の製鉄工程への 適用

1000 万トンモデルプラントの内容に 従い各設備の稼 動率およびェネルギー原単位を想定し，エネルギーバラ ンスを作成した結果，モデルプラントの粗鋼 $\mathrm{t}$ 当たりの 電力原単位は $485 \mathrm{kWh} / \mathrm{t}$ と算出された。したがつて平 均使用電力は $555 \mathrm{MW}$ となり，この電力を単純に原子 力発電の電力に置き換えるとほほ $500 \mathrm{MW}$ の原子力発 電所に相当する. まず，単基 $500 \mathrm{MW}$ を基準ヶースと して，これと共同電力またはコンビナート方式を予想し た $1000 \mathrm{MW}$ の軽水型原子力発電所について送電単価 の試算を行ない，共同火力発電所 $(125 \mathrm{MW} \times 2$ 基, $375 \mathrm{MW} \times 2$ 基)の場合と比較した.

原子力発電所の稼動率の決定は, 今後の技術的進歩を 考虑し, 定期検査に 2 力月を予測し事故なども含めて稼 動率 $80 \%$ として，その送電単価を共同火力と比較した のが表 8 である.すなわち「自家用原子力」は発電単価 は安いが, 停止時の自家発予借電力料金が高く電力費は 高くなる. 一方「共同原子力」はスケールメリットを十 分に発揮して電力費は安くなり，その節隇額は昭和 50 
表 61000 万トンモデルプラントの設 備

\begin{tabular}{|c|c|c|c|c|}
\hline 設 備 名 & 能 & 基数 & 産量 & $\frac{\text { 年間操業時間 }}{\text { 暦年年間時間 }} \times 100$ \\
\hline 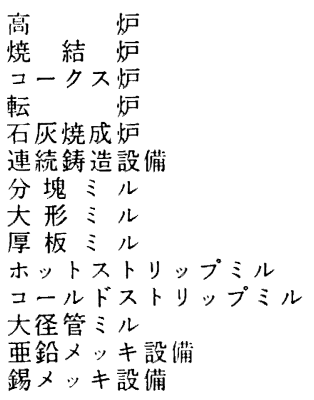 & 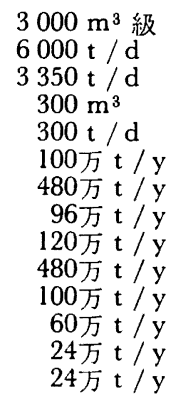 & $\begin{array}{l}4 \\
4 \\
4 \\
6 \\
6 \\
2 \\
2 \\
2 \\
2 \\
1 \\
2 \\
1 \\
3 \\
1\end{array}$ & 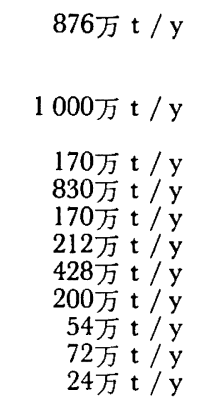 & $\begin{array}{l}95 \% \\
95 \% \\
100 \% \\
95 \% \\
75 \% \\
72 \cdot 3 \% \\
80 \% \\
80 \% \\
85 \% \\
85 \% \\
70 \% \\
85 \% \\
85 \%\end{array}$ \\
\hline
\end{tabular}

表 7 原子力発電による発電コスト

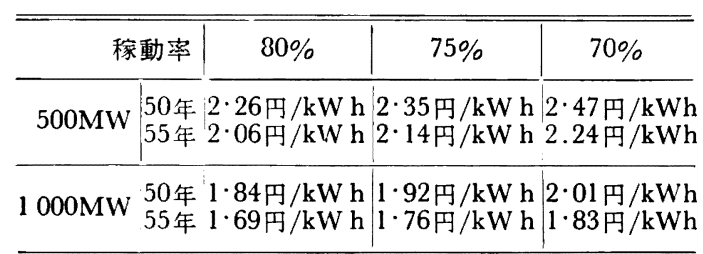

表 8 発電単価の比較 （共同火力 $=100$ とする）

\begin{tabular}{|c|c|c|c|c|c|}
\hline & \multirow{2}{*}{$\begin{array}{l}\text { 共同 } \\
\text { 火力 }\end{array}$} & \multicolumn{2}{|c|}{ 自家用原子力 } & \multicolumn{2}{|c|}{ 共同原子力 } \\
\hline & & 50年 & 55年 & 50 年 & 55 年 \\
\hline $\begin{array}{l}\text { 発 電 原 価 } \\
\text { 補充(予備)料金 } \\
\text { 買 電 料 金 }\end{array}$ & $\begin{array}{l}100 \\
100 \\
100\end{array}$ & $\begin{array}{r}97 \\
165 \\
100\end{array}$ & $\begin{array}{r}89 \\
165 \\
100\end{array}$ & $\begin{array}{r}79 \\
133 \\
100\end{array}$ & $\begin{array}{r}72 \\
133 \\
100\end{array}$ \\
\hline 合 & 100 & 109 & 104 & 93 & 89 \\
\hline
\end{tabular}

年度完成の場合で年間 9.3 億円, 55 年度完成の場合で 14.5 億円が期待される. しかしながらここで想定した 原子力発電所は単基発電であるため，保安電力対策，負 荷の变動に伴う電圧変動対策，あるいはガスの消化対策 などいろいろの問題が残されている.

\section{$3 \cdot 3 \cdot 2$ 製鉄プロセスの変換}

銑鉄製造法は現在高炉法が主流であるが，変換プロセ スとして現在工業的に操業されかつ電力を多量に消費す る電気製銑炉法を選定した. 電気製銑法は一炉当たりの 生産規模が小さく，また銑鉄 $\mathrm{t}$ 当たり $1000 ２ 500 \mathrm{kWh}$ と多量の電力を消費するため，現在では特殊な条件にあ る場合のみ成立している. 電気製銑炉の能力は，今後の 大型化を考虑しても電極径 $1900 \mathrm{~mm}$, トランス容量 $65000 \mathrm{KVA}$ が一応の技術的限界点と考えられる.なお, その特徽として，還元剤としては，入手が容易で安価な 弱粘結炭が使用できる.
比較の対象を $3000 \mathrm{~m}^{3}$ 級高炉に求めた場合, 高炉 1 基の生産能力に見合う上記電気製銑炉の必要基数は「木 ットチャージ法」では 6 基,「コールドチャージ法」で は 2 基となり，これらを基に銑鉄単価を算出し経済性を 比較した．電気製銑法での鉄鉄単価は電力費により变動 し，高炉法と経斉的に対抗できるのは 1.5 円/ $\mathrm{kWh}$ 以下 の場合であることがわかつた。

電気製銑法では安価な弱粘結炭が使用できるメリット がある反面, 単位設備の生産性の制約, 製銑部門の土地 占有面積, 発生ガスの利用などプロセス変換上の問題点 が残されている。

\section{$3 \cdot 3 \cdot 3$ 製鋼プロセスの変換}

製鋼プロセスの経済性の比較は LD 転炉 (200 $\mathrm{t}$ 炉 $\mathrm{x}$ $4 / 6$ 基操業）と電気製鋼炉について行なつた. 製鋼用電 気炉は今後の大型化と超高電力操業への䞶勢から $300 \mathrm{t}$ 炉，トランス容量 $170000 \mathrm{KVA}$ とし，この平均電力原 単位を $450 \mathrm{kWh} /$ 溶鋼 $\mathrm{t}$ とすると, 必要基数は 9 基整 備の 7 基稼動となる.

転炉の主原料構成はそのスクラップ単価を 15000 円/ t と 18000 円/t の二通りに評価し，その混銑率をそれ ぞれ 70\%，80\% とした．電気炉の主原料として還元鉄

（外部より供給されるとする）を選定し，これを連続装 入するものとする. 還元鉄組成は M. Fe 90\%，その配 合率を $80 \%$ とし, スクラップ単価は転炉の場合と同じ とする. 電気炬鋼溶鋼単価はその主原料である還元鉄単 価および電力単価により变動するが，電力単価を 1 .5 円 $/ \mathrm{kWh}$ とした時の溶鋼単価の比較は図 4 のごとくであ り，これより転忓鋼に匹敵する還元鉄の価格が求められ る.

また，電力単価が 1 円上昇した場合には還元鉄価格が 500 円下降しないと変換プロセスは経済的に成立しな い.この検討結果は原子力製鉄により生産される還元鉄 の経済性の目安となるものである. 


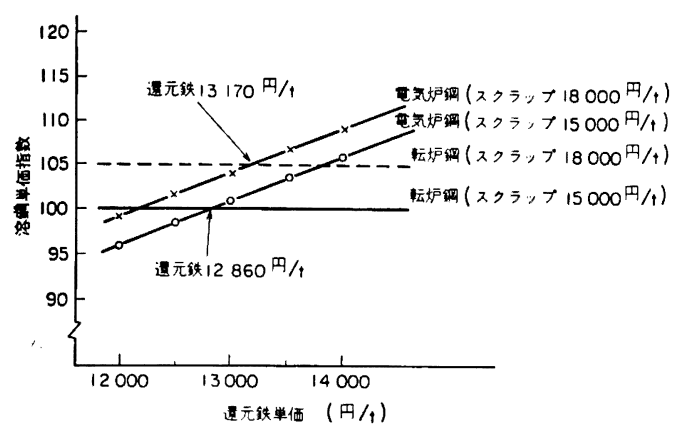

因 4 還元鉄単価による電気炉鋼溶鋼単価の変動 (電力価格 $1.5 \mathrm{P} / \mathrm{kWh}$ )

表 9 変換プロセスの成立する電力価格

\begin{tabular}{|c|c|}
\hline 設 備 名 & 電 力 価 格 \\
\hline $\begin{array}{l}\text { 分塊均 熱 炬 } \\
\text { 大形連続加熱炉 } \\
\text { 厚板連続加熱炉 } \\
\text { "焼 鈍 炉 } \\
\text { ホット連続加熱炉 } \\
\text { コールト焼鈍炉 }\end{array}$ & 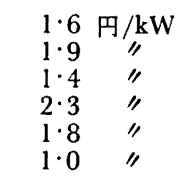 \\
\hline
\end{tabular}

3.3.4 加熱プロセスの变換

現在の一貫製鉄所の圧延用加熱师の熱源は主として B ガス， Cガスなど副生ガスに依存しているが，将来直接 還元一電気炉製鋼という組合せの製鉄所が 実現した時 は, 他の熱源によらなければならない.したがってここ では加熱师熱源への電力の利用という面から電気誘導加 熱による鋼材の加熱の経済性について検討を加える.

電気誘導加熱は電気エネルギーを熱エネルギーとして 直接变換し,材料自体が発熱昇温する方式であるため, 燃 焼加熱に比べ加熱勃率がよい，鋼材内外の温度差が少な い，加熱時間が短くてよい，スケール発生量が少ない， 自動制禦が容易，排ガスが出ないなどのメリットがあ る. その他エネルギー効率も高く操作も簡単で炉の稼動 率, 生産性む良好である. 経済性の検討は加熱炉費につ いて行なつたが，これは主として燃料費とスケールロス 分に左右される.燃焼炉のスケール発生は 1 1.5\%の 範囲にあるが, 誘導炉では $0.2 \%$ 程度である.燃焼炉の熱 源価格として $0 \cdot 7$ 円 $/ 10^{3} \mathrm{kcal}$ を採用すると電気誘導加熱が 経済的に優位になる電力洒格は表 9 の如く求められた.

次いで 1000 万トンモデルプラントの所要電力量につ いて検討を加えた.この場合製鉄プロセスは還元鉄装入 の電気炉製鋼一電気誘導加熱とすると, 総所要電力量は 約 $2250 \mathrm{MW}$ に達し, 原子力発電所のスケールメリッ トによる電力価格の低下が十分期待できる值であるが, 現在引続きこの場合の電力価格予想値, その他電力上の 諸問題について検討を加えている.

\section{4 第 2 小委员会関保（原子力熟エネルギーの利用）}

第 2 小委員会においては原子力熱エネルギーの製鉄プ
ロセスへの直接利用に関する調査, 検討を行なうために 現行高炉製銑プロセスへの直接利用を検討するワーキン グ・グループと, 直接還元法への直接利用を検討するワ ーキング・グループ両者を設けて活動を行なつている. さらに,図 3 に示した流動層WG は, いわゆる高温域流 動層法を技術的に検討しょうとするものである.

3.4.1 原子力熱エネルギーの高炉プロセスへの利用

高炉に必要な良質の強粘結炭を入手することは，価格 的な条件も考慮に入れて，ますますきびしさを増すこと が予想され，コークス消費量を減少させることはもちろ え，多量消費のコークスを原子力熱エネルギーのような 他のエネルギーに転換させていくことを考えなければな らないが，今日隆盛を極めている大型高炉に原子力熱工 ネルギーを利用することはまず第一に考えるべき課題で ある.ここにおいて高炉プロセスへの原子力熱エネルギ 一の利用の可能性については，第一に高炉に吹込えでい る熱風を原子力熱エネルギーで加熱する方法が考えられ る.これはコスト的にも, 副生ガスの有効利用という 点からも熱風炉加熱用高炉ガスを原子力熱エネルギーに より代替することで得策でない，第二は原子力熱エネル ギーで製造, 加熱した還元ガスを高炉腹部へ吹込む方法 である.この方法によれば現在大型高炉に吹込まれてい る重油量よりさらに多量の燃料吹込みが可能となりコー クス比の低下が考えられるので，この方法について調査 と理論的検討を行なつた。そ結果，不純物の少ない $1000^{\circ} \mathrm{C}$ 以上の還元ガスを装入物温度が $800 \sim 1000^{\circ} \mathrm{C}$ 以上の直接還元のおこる領域以上のできるだけシャフト 下部から吹込むことが有利であり, 理論的な最低コーク ス比は溶解炭素を含めて $220 \sim 260 \mathrm{~kg}$ と推定された. ま たコークス価格 10000 円 $/ \mathrm{t}$, 重油 7000 円 $/ \mathrm{t}$ とした場合, 吹込み還元ガス価格が $\mathrm{Nm}^{3}$ 当たり少なくとも約 3 円程 度になれば経済的に成り立つことが推定された. 以上の ごとく高炉製銑プロセスへの原子力熱エネルギーの利用 は還元ガスの温度と価格によつてはその可能性があると 考えられた。

$3.4 \cdot 2$ 原子力熱エネルギーの直接還元法への利用 現在までに報告されている直接還元法は，その原理， 規模などさまざまであり，ある特定の地域の鉱石，燃料 などの条件において開発されたプロセスが多い。したが つて一般性があり，スケールアップが可能で，なおかつ 原子力熱エネルギーが有効に利用できる直接還元プロセ スを選択することが重要となる. ワーキング・グループ においては多くの直接還元プロセスを表 10 に示すごと く7分類して, これらの各プロセスの代表的なものにつ いて原子力熱エネルギーの利用の可能性について検討し た.

（1）流動層法一一代表的なものとして H-Iron 法, Nu-Iron 法, F10R 法などがある.これは粉鉄鉱石を 還元ガスによつて浮遊させながら還元するもので, 特徵 
表 10 直接浐元法の分類と代表的プロセス

\begin{tabular}{|c|c|}
\hline 分 類 & 代 表 例 \\
\hline 流 動 層 法 & H-Iron 法, Nu-Iron 法, F10R 法 \\
\hline シャフト炉法 & $\begin{array}{l}\text { Midrex 法, Purofer 法, Wiberg- } \\
\text { Söderfors 法, 日立金属 Wiberg 法 }\end{array}$ \\
\hline $\begin{array}{l}\text { ロータリー } \\
\text { キルン法 }\end{array}$ & $\begin{array}{l}\text { SL/RN 法, Krupp-Renn 法, } \\
\text { Elektrokemisk 法 }\end{array}$ \\
\hline レトルト炉法 & HYL 法, Höganas 法 \\
\hline 移 動 床 法 & D-LM 法, Heat-Fast 法 \\
\hline 電 気 炉 法 & $\begin{array}{l}\text { Albert de Sy 法, Lubatti 法, } \\
\text { Baglio-Tradardi 法 }\end{array}$ \\
\hline 塎融還元法 & $\begin{array}{l}\text { Eketorp 法, Cyclo-Steel 法, } \\
\text { Jet-Smelting 法 }\end{array}$ \\
\hline
\end{tabular}

は粉鉱石の反态面積，還元速度が大であることを利用す るため, 還元ガス温度はやや低目であつても操業できる ことである. 一方欠点としては還元過程において流動を 阻害する還元鉱石の焼結現象がある.この問題を克服す れば原子力熱エネルギーは還元ガスの製造と加熱, 鉱石 の予熱に大幅に利用できる. EEC における調査, 研究 においてもこのプロセスを有力なものとして検討してい る.

（2）シャフト炉法—この方法はペレット，塊鉱石 の向流式ガス還元法であり, 長所は設備が簡単で生産性 が高いことである. また問題点としては装入物の円滑降 下, 還元ガスの炉内均一上昇, 鉱石と還元鉱の給排出機 構などがあげられる. 現行プロセスにおいては，CO と $\mathrm{H}_{2}$ の混合ガスを約 $1000^{\circ} \mathrm{C}$ に加熱して還元炉に送入し ているが， $850^{\circ} \mathrm{C}$ 以上の還元ガス温度が得られるなら ば，装入鉱石の予熱などを行なうことによつて反応率の 大幅な低下はさけられると考えられる。したがつてシャ フト炉法は原子力熱エネルギーの利用可能なプロセスで ある.

（3）ロータリーキルン法一この方法は工業的にも 広く用いられている方法で，代表的な例として SL/ RN 法, Krupp-Renn 法, Elaktrokemisk 法などがあ る. 回転邩内の伝熱はバーナーの火炎からの放射伝熱が 主であるため，これを原子炉からの $\mathrm{He}$ の顕熱で代替す ることは温度の点と, 回転炉の構造上からむ困難である.

（4）レトルト炉法一ここの方法の代表例はメキシコ の HYL 法である. 特徵はバッチ式に操業する点である が，その他の点はシャフト炬法と大体同じである. した がつて原子力熱エネルギーの利用は可能な方法といえる が，操業がバッチ式であり，生産性にも難点があつて設 備費が高くなるなど原子力製鉄の対象プロセスとは見な しがたい。

（5）移動床法一一代表例としては D-LM 法, Heat-
Fast 法などがある。これは固体還元刘を内装したペレ ットを原料とし, 還元戍中の揮発分, 炭素の部分燃焼に よる熱を利用して $1200 \sim 1300^{\circ} \mathrm{C}$ 个急熱し，還元骫の 全部は消費されないような短時間内に還元を行なわせる ことを特徴とする。したがつて生産性は高いが還元率は 低い. 以上の点から判断して, 加熱温度が高いので原子 力熱エネルギーの利用は困難である.

その他電気炉法, 溶融還元法なども検討したが，原子 力製鉄として検討の対象とはなしえなかつた.

以上, 高炉プロセスと直接還元法への原子力熱エネル ギーの直接利用について検討した.この結果高温ガス炉 の $\mathrm{He}$ 出口温度 $1000^{\circ} \mathrm{C}$ を用いて 得られる 還元ガス温 度を $850^{\circ} \mathrm{C}$ とするならば, この還元ガス温度では十分 ではないが，原子力製鉄を実施できるプロセスの対象と しては流動層法とシャフト炉法が考光られるとの結論を 得た.

原子力部会として注，この 2 つのプロセスの国内, 国 外の情報を収集すると共に, 実用化における基礎資料を 得ることが重要と考光, 前述のごとく流動層ワーキン グ・グループを新たに設置して調査, 問題点の抽出を行 なつている.一方シャフト炉法については, 国内的にも 日立金属-Wiberg 法などデーターの蓄積もかなりある ので流動層法に優先して実験を先行させることとなり， 部会にシャフト炬小委員会を設置して，45 年度より共 同実験を開始した

\section{$3 \cdot 4 \cdot 3$ シャフト炉による直接還元の基礎実験}

昭和 45 年度通産省重要技術研究 開発費補助金を受 け，鉄銅 7 社共同によるシャフト炉還元実験を行なつ た.これは新日鉄基礎研究所内に設置された日産 500 $\mathrm{kg}$ 規模の実験炉を用い，原料ペレット銘柄，還元条件 を種々に組み合わせて基礎研究を行なうもので 45 年 7 月末実験設備完成後 4 回の連続試験を実施した. 図 5 に 試験設備のフローシートを, また表 11 に試験条件と試 験結果の一部を示したが，要約すると次のようになる.

（1） 製品還元率については，還元ガスとして $95 \%$ 程度の $\mathrm{H}_{2}$ ガスを使用した場合 $700^{\circ} \mathrm{C}$ 以上の還元温度 と, 約 $2000 \mathrm{Nm}^{3} / \mathrm{t}$-製品以上のガス量で, $95 \%$ 以上が 達成された、還元ガスに CO が添加された場合は，還 元率溚干低下する.

（2）還元温度が $950^{\circ} \mathrm{C}$ の場合, 還元率 $90 \%$ 以上の 製品が $25 \mathrm{t} / \mathrm{m}^{3}$.day 以上の生産性で得られた.

（3）良質なペレットを原料として定常運転を行なつ た場合, 還元温度 $950^{\circ} \mathrm{C}$ でもペレットの融着によるト ラブルなしに操業することができた.

なお，シャフト灯小委員会では，還元ガス中の $\mathrm{CH}_{4}$ の影響を検討するため，今年度も試験を継続することに なつている.

\section{5 第 3 小委員会関保（製鉄用原子炉）}

第 3 小委員会は，原子力製鉄に打ける原子炉の開発と 

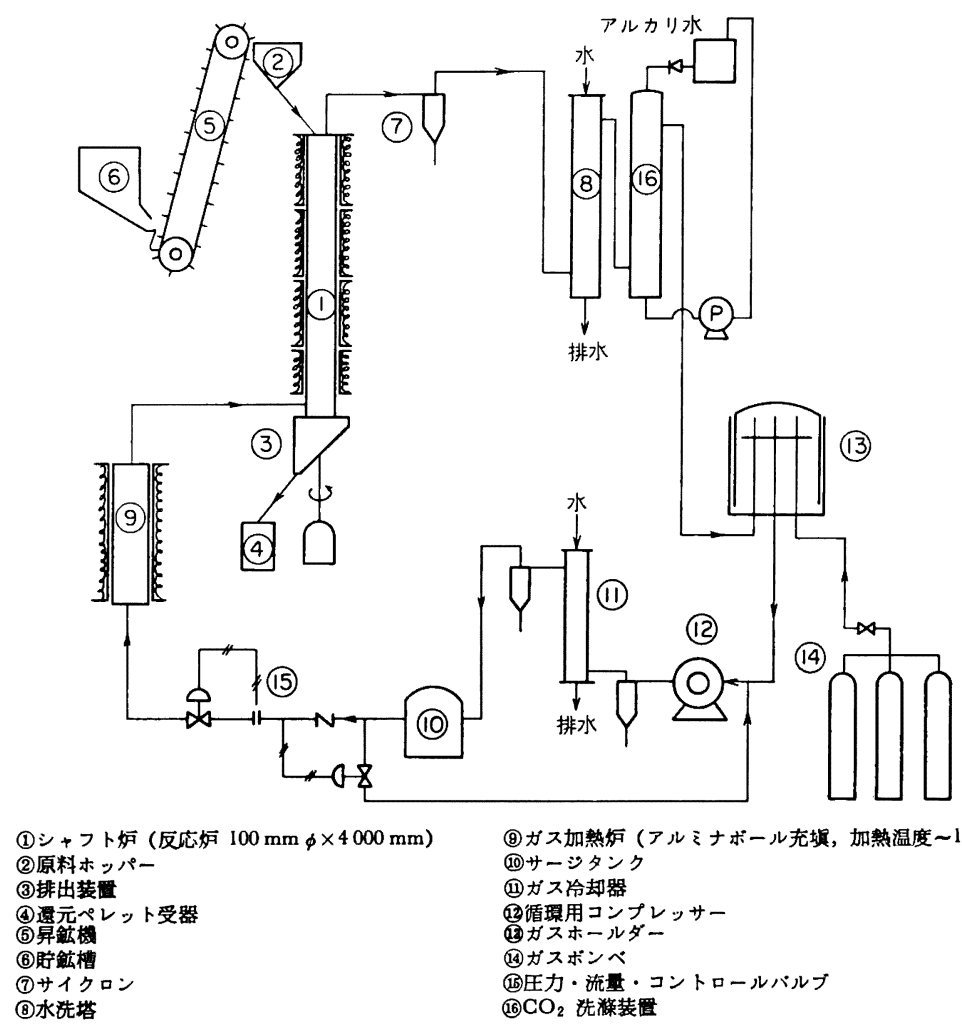

(2)ガス加熱炉 (アルミナボール充垻，加熱温度〜 $1000^{\circ} \mathrm{C}$ ) (10サーシタンク

(11)ガス冷却器

(13)佰摆用コンプレッサー

(24)カススーールダー

(14)ガスボンヘ

(16)压力・流量・コントロールバルブ

(16) $\mathrm{CO}_{2}$ 洗漠蓄㯰

因 5 シャフト师実験炉設備フローシート

表 11 シャフト炉実験の試験条件と結果

\begin{tabular}{|c|c|c|c|c|c|c|c|}
\hline & $\begin{array}{c}\text { 還元ガス組成 } \\
\%\end{array}$ & $\begin{array}{l}\text { 還元ガス量 } \\
\text { (l//min) }\end{array}$ & $\begin{array}{c}\text { 罯元温度 } \\
\left({ }^{\circ} \mathrm{C}\right)\end{array}$ & $\begin{array}{c}\text { 原料装入量 } \\
(\mathrm{kg} / \mathrm{hr})\end{array}$ & 哀 & $\begin{array}{c}\text { ガス利用率 } \\
(\%)\end{array}$ & 生 産 性 ! \\
\hline $\begin{array}{l}\text { 第 } I \text { 期 } \\
\text { 連 } \\
(45.8 .6 \sim 45.8 .14)\end{array}$ & $\begin{array}{l}\mathrm{H}_{2}: \\
92 \sim 98 \% \\
\mathrm{~N}_{2}: \text { 牫 } り\end{array}$ & $\stackrel{500}{?} 1000$ & $\begin{array}{c}700 \\
? \\
950\end{array}$ & $\begin{array}{c}17 \\
? \\
48\end{array}$ & $\begin{array}{c}69 \cdot 0 \\
100\end{array}$ & $\stackrel{25 \cdot 1}{?}$ & $\begin{array}{c}9.2 \\
28 \cdot 0\end{array}$ \\
\hline 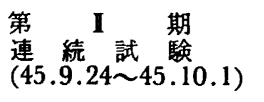 & $\begin{array}{l}\mathrm{H}_{2}: \\
89 \cdot 5 \sim 97 \cdot 8 \\
\mathrm{~N}_{2}: \text { 残 } り\end{array}$ & $\stackrel{500}{?}$ & $\begin{array}{c}700 \\
870\end{array}$ & $\begin{array}{c}19 \cdot 5 \\
? 9 \cdot 5\end{array}$ & $\stackrel{69 \cdot 6}{?}$ & $\stackrel{20 \cdot 5}{?}+\frac{1}{47 \cdot 0}$ & $\begin{array}{c}10 \cdot 9 \\
27 \cdot 8\end{array}$ \\
\hline $\begin{array}{l}\text { 第 } \\
\text { 連 } \\
(45.11 .25 \sim \text { 続 } \\
\text { 試 }\end{array}$ & $\begin{array}{l}\mathrm{H}_{2}: 70 \sim 95 \\
\mathrm{CO}: 0 \sim 25 \\
\mathrm{~N}_{2}: \text { 残り }\end{array}$ & $\begin{array}{l}390 \\
? \\
880\end{array}$ & $\stackrel{700}{?}$ & $\stackrel{31 \cdot 4}{?}+\frac{}{54 \cdot 5}$ & $\begin{array}{c}85 \cdot 0 \\
? \cdot 3\end{array}$ & $\begin{array}{c}36 \cdot 4 \\
57 \cdot 4\end{array}$ & ${ }_{35 \cdot 2}^{18 \cdot 4}$ \\
\hline 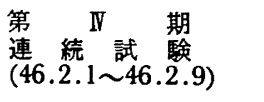 & $\begin{array}{l}\mathrm{H}_{2}: 43 \sim 95 \\
\mathrm{CO}: 0 \sim 40 \\
\mathrm{~N}_{2}: \text { 残 }\end{array}$ & $\overbrace{750}^{390}$ & $\begin{array}{c}700 \\
? \\
950\end{array}$ & ${ }_{40 \cdot 0}^{30 \cdot 0}$ & $\stackrel{80 \cdot 0}{?}$ & ${ }_{48 \cdot 0}^{30 \cdot 0}$ & $\begin{array}{c}13 \cdot 7 \\
39 \cdot 8\end{array}$ \\
\hline
\end{tabular}

[注] 原料ペレット：カイザー,ワイヤラ, サベーシリバー 試䀢娔成ペレット（㙁基度 $0,0.5,1.0,1.5$ )

研究を目的としている. 当初諸外国の高温ガス炉の文献 を調查することから始め, GGA の高温ガス炉（ピーチ ホトトム炬とフォート・セント・ブレイ的) OEGD の

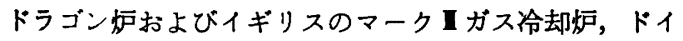

ツの AVR，さらに超高温炉 UHTREX，溶融塩炉およ び特殊高温炉について調查し, 昭和 44 年 5 月高温ガス 炬に関する調查報告をまとめた. 原子力製鉄用として $1000 \sim 1200^{\circ} \mathrm{C}$ の原子炉出口温度を有する冷却刘が必要 
な場合に垱当 He ガス泠却高温ガス炬が唯一のもので あることを報告した．当時運転中の高温ガス炉の出口温 度はピーチボトム炉とドラゴン炉が $750^{\circ} \mathrm{C}$, AVR が $850^{\circ} \mathrm{C}$ であり, UHTREX は運転にいたらず, 計画中 の高温ガス泠却発電炉ではいずれも $750^{\circ} \mathrm{C}$ 前後であつ た（ロスアラモス研究所の UHTREX はその後運転を 開始し $1300^{\circ} \mathrm{C}$ で運転されているが，これは高温を出 すために特殊な設計がなされたもので，この設計を実用 炉に適用することは問題がある.）したがつて He ガス の原子炬出口温度 $1000 \sim 1200^{\circ} \mathrm{C}$ の高温ガス炉を開発 するためには実験炉から始めることが必要であり，この ような実験炉は当時の状況からみて, 世界の高温ガ、炉 開発に貢献できるものであり，またわが国の国情を背景 に高温ガス炉開発を地道な軌道にのせるのにも有益であ ると判断した.

この考えに基づき，設計ワーキンググループを設け実 験炉の基本構想を検討した。この実験炉としては被覆粒 子燃料を使用するHe冷却高温ガス炉で, 炉心出口温度は $1200^{\circ} \mathrm{C}$ 程度の極力高温を目標としたもので, 出力は将 来の原型炉へのスケールアップファクターと燃料照射べ ッドとしての炉心サイズを考虑して，熱出力 $50 \mathrm{MW}$ を 想定した．また原子力製鉄プロセス開発のためには，高 温のガスーガス 熱交換器が原子炉と同じく重要な実験設 備であるので，炉出力の高温部分約 $40 \%$ をガスーガス熱 交換器で吸収し，低温部分を水冷却で除去する冷却方式 を提案した. 二次系ガス冷却材としては当時十分な資料 がないまま炭酸ガスとしたが，その後第 4 小委員会など の検討の結果水素あるいは水素と一酸化炭素の混合ガス を使用する方向に改められた。 また建設, 実験の融通性 をもたせるため原子炉本体と熱交換器は分離型とし，鋼 製二重圧力容器を使用する方式とした。

その後部会の方針により, 実験炉開発に関しては原研 に委ね，原型师あるいは実用規模の大型の製鉄用高温ガ ス炉に関する技術的評価および立地安全性の問題を研究 することとなつた．原子炉の場合, 同じ $1000^{\circ} \mathrm{C}$ の出 口温度を出す場合でも，小型でありかつ種々の項目につ いての実現性のテストを主眼とする実験炉と大型実用炉 とでは, その情造, 材料工学的安全施設など大きく異な る面があることから，大型炉の技術的検討を行なうた め, 昭和 45 年 7 月, 製鉄用高温ガス炉評価ワーキング グループを発足させた. 同ワーキンググループでは一応 $\mathrm{He}$ の出口温度 $1000^{\circ} \mathrm{C}$ の大型炉を想定して検討を進め ることとし，コンクリート圧力容器 (PCRV) など他で 研究されているガス炉の一般的な問題はできるだけ省略 し，高温ガス炉で炉出口温度を現在の $750 \mathrm{C}$ から 1000 ${ }^{\circ} \mathrm{C}$ に上げる際の問題点, あるいは還元ガス中の水素がへ リウム側入拡散する問題のように製鉄用として使用する ときに生ずる問題点などに重点を置くよう配虑してい る.
検討された主要な問題は以下の如くである. 現在の被 覆粒状燃料は $1400 \sim 1450^{\circ} \mathrm{C}$ 程度までは安定であるが それ以上の温度で注次第に損傷を受ける. したがつて $\mathrm{He}$ の平均出口温度と燃料最高温度の差を極力小さくす るような炉心の核熱設計，灿心の構造材である黒鉛の照 射に対する安定性および二次側の還元ガスから一次 $\mathrm{He}$ に拡散透過してくる水素と黒鉛との反応，酎熱材料およ び PGRV のライナーなどの内張りに使用される咪熱 材料, 炉の悽造, 取替之燃料方式の場合の炉心の耐震構 造, $\mathrm{He}$ サーキュレーター. チタンスポンジによる水素 除去装置，緊急遮断弁などである，さらに原子炉と製鉄 プロセスの結合や溶融鉛，溶融ナトリウムによる熱交換 の検討も進められている.

製鉄用高温ガス炉評価ワーキンググループで，炉およ び PCRV の耐震懳造など安全性に関する問題が次第に 解明されてきたので，これを受けて，昭和 46 年 2 月， 安全性ワーキンググループが設けられ，とくに安全性の 問題を取上げて研究することになつた，原子炉はその開 発の歴史からみても，安全性には慎重な注意が払われ， 所謂無公害を前提として建設されてきた. 開発初期にお いては原子炉の危険性についての知識の欠如から，最終 的な安全の確保は人口密集地域から遠隔の地に設置する ことにより保証するという方針がこられた．現在では原 子师に関する知識, 経験が蓄積されるとともに，このよ うな考えから工学的安全施設などにより安全を確保する 方向に変わりつつある. 原子力発電の場合は送電により 発電所は人口密集地域から離すこともできるが，原子力 製鉄の場合は必然的に原子炉を製鉄所内，あるい注コン ビナート内の如く, 原子力発電所に比して比較的人口の 多い地域に設置せねばならないと予想される。したがつ て原子炉自身の安全性および立地は非常に重要な問題で あり，対策をたてるべく検討をすすめている.

\section{6 第 4 小委員会関係（熱交換器）}

前述のように原子力熱エネルギーの製鉄プロセスへの 利用に当たつては, 高温 $\mathrm{He}$ ガス（原子炉出口 $1000^{\circ} \mathrm{C}$ またはそれ以上）の顕熱を効率的に製鉄側に伝達するこ とが重要であり，その接点部分に当たる熱交換器技術の 開発の成否がきわめて大きい. そこで第 4 小委員会とし ては, まず高温ガスーガス熱交換器の現状の使用実態の 内容調査から着手した.ガスタービン, MHD 発電, 化学 プラント，実用ガス冷却原子炉，また EEC が行なつた 原子力製鉄の模討に使用された熱交換器などを対象とし て検討した．一般に使用温度条件は，今回当部会で目標 とされている温度より相当低目であり，直接的に利用し うるものはないが，一般的な傾向を調査しえた。

\section{(1) 熱交換器形式の検討}

第 4 小委員会では, 熱交換器の設計構造の前提となる 熱交換の基礎条件一一直接型か間接型か一一問題につ いても検討を続けてきた. 直接熱交型は高温 $\mathrm{He}$ の顕熱 
を隔壁を通して，直接熱を与えるもので $\mathrm{He}$ ガス側への $\mathrm{H}_{2}$ の透過, 炉側の核分裂生成物の漏洩などに対する安 全性が確保されるならば明らかに間接型より著しく大き なメリットを持つている. $\mathrm{H}_{2}$ の透過についてては $\mathrm{H}_{2}$ と炉心グラフォイト楧造との反応 $\mathrm{C}+2 \mathrm{H}_{2} \rightarrow \mathrm{CH}_{4}$ の平 衡は高温ほど分解側へ進み, 少量の $\mathrm{H}_{2}$ 洩入であれば実 際上は問題とは交りがたいという見方がありうることも 検討された．また間接熱交換器流高温 He の顕熱を中間 熱媒体を経て与えるもので安全性㳭証されるが，2 重 熱交換に伴う設備上, 経済上の不利が大きくなること, 間 接熱交型の場合の媒体としては, 水蒸気, He または溶 融鉛が候補として考えうることなどが検討された．この 結果, これらの技術的問題点を解明し, 開発の方向を究明 するため, $\mathrm{H}_{2}$ 透過の実態の把握と除去対策の技術, 中間媒 体としての水蒸気と He ガスの熱交換に関するテーマな どを包含する実験を施行する必要性があると結論した。

（2）耐熱金属材料に対寸る検討

高温熱交換器でもつとも問題となるのは材料選択と, その開発に関するものである. 原子力製鉄用熱交換器の 金属材料としては $1000^{\circ} \mathrm{C}$ またはそれ以上の㻴境下で，

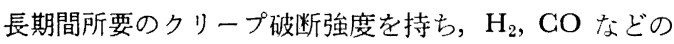
雾囲気の中で, 滲炭, 部分酸化, $\mathrm{H}_{2}$ 脆化などの現象に対し て酎久性があり，また材料加工，溶接性にょういて問題を 生じないこと，さらにコスト的にも実現可能性があるこ となどのむずかしい条件がつく．これに対し第 4 小委員 会では, わが国における各種の耐熱合金に対し, 主とし て高温強度の点から, その適用の可否, 問題点の集約を 行なつた. $\mathrm{Fe}$ 基, $\mathrm{Ni}$ 基, $\mathrm{Co}$ 基の耐熱合金の調査対象 材を表 12 に例示した. この検討の結果を一括すると次 のようになる. (1) $1000^{\circ} \mathrm{C}$ までの使用温度に対しては,

現在実用中である $\mathrm{Fe}$ 基合金のインコロイ $800, \mathrm{Ni}$ 基 合金のインコネル 600, ナイモニック 90，インコネル Xなどが対象として考えられ，その使用期間に制限を設 けることにより使用可能と考えられる. (2) HK 40, HP, supertherm などのステンレス系遠心鋳造管材は, 前項 の鍛造用合金材料に比し，対高温特性は良好となるが， 小径，薄肉，長尺管の製造方法の開発，延性の低小欠点 を設計で補うなどの措置が必要である. (3) Co 基合金, 高融点金属にも有望な合金はあるが, 加工性, 価格面, 実用化までの開発期間などに問題がある.

以上から $\left(1000^{\circ} \mathrm{C}\right.$ を目標とする $\mathrm{He}$ ガス温度に対応 出来る耐熱材料としては, 当面, 上記 $\mathrm{Fe}, \mathrm{Ni}$ 基合金を操 用し，使用条件については自重と熱応力以外の機械的応 力を極力下げ，クリープ問題を低減するよう設計上配虑 することと，使用期間に制約を付すことなどの弾力的な 考えによつてカバーすべきであると結論した。

(3) 熱交換器の情造設計に関する検討

高温のガスーガス熱交換器は, その性能, 耐久性, 原 子炉側よりの灾全性の問題や経済性などを考虑して，そ
の型式，構造，寸法，材料を決定すべきであるが，高 温，高压，大熱量のみならず，1 次側 $\mathrm{He}$ ガス中には核 分裂生成物が含をれるのだ，その安全性をも考虑した複 雑な構造の大型厚肉の熱交換器となる. 前述のごとく, 高温用熱父換器では材料強度低下のため, 機械的応力と 熱応力の和を許容忍力以下に抑える必要がある. その絬 果熱流束の大きさに制限が加わり，この熱流束はクリ一 プ考虑係数と降伏応力との積に依存するなど，高温熱交 換器特有の問題があるので, 熱応力を考虑した構造の検 討などを行なつている．さらに設計上，製作上の問題点 については，大型高温の金属管隔壁熱交換器についての 実績が全くないので， $\mathrm{He}$ 一還元ガス熱交換器に近い条 件下で使用されるスチームリフォーマにつき調査検討を 加えた. 反応管は 5〜40 気圧, 使用温度 $700 \sim 900^{\circ} \mathrm{C}$ で，HK 40 の鋳造管で一端固定で熱膨張を逃げるよう 設計されている. 往来の損傷原因の大部分は，炭化物の 析出, 浸炭腐食, シグマ相形成による脆化, 割れ感受性 の増大などで $\mathrm{H}_{2}$ に起因する問題は少ないことがわかつ た. 以上より, 熱交換方式, 縦型か横型かの選択, 管の支 持法, 熱応力対策, 工作, 溶接法, 断熱材の使用法, 耐 震性などを考虑する必要があると考えられた。いずれに しても, 設計研究, 安全性試験, 流動伝熱試験を順次ス ケールアップし, いずれメガワット級の熱交換器を実験 原子炉ループに併設して熱交換器としての特性試験を行 なうことの必要性が検討された。

（4）昭和 46 年度共同実験

上記検討の結果，原子力部会として早急に熱交換器開 発の基礎実験を開始すべき必要性をみとめ, 昭和 46 年 度の共同実験として 17 社（鉄鋼会社，機器製作メ一力 一・特殊金属材料メ一カー）参加による実験を準備中で ある、これには $\mathrm{H}_{2}$ 透過と除去に関する技術調查と閒 発, $\mathrm{He}$ 一水蒸父の熱交換, 楧造上問題となる熱応力現 象の第一次的把握耐熱金属材料の榆討などを検討項目と している.

\section{7 第 5 小委員会関係（遦元ガス製造）}

\section{$3 \cdot 7 \cdot 1$ 還元ガス製造方式の検討}

将来実現されるべき原子力熱エネルギー使用の製鉄プ 口セスには大量の還元用ガスが必要とされるが，その原 料は産業全体, とくに石油精製, 燃料ガスおよび石油化 学工業との関連において考えられねばならない. 第 5 小 委員会においては現存の還元ガス製造技術のみに止まら ず，向後数年間に開発完成を予定されている新技術まで を含め, 産業全体における炭化水素源最適使用の立場か ら還元用ガス製造プロセスを検討し, 原子力熱エネルギ 一利用の方法およびプロセスシステムの大綱を策定する 事を目途としている.

当初は原子力製鉄と還元ガス製造の関連および現存の ガス化技術に関する資料蒐集を主としたが，その後原子 力製鉄プロセス実現時における炭化水素原料の見通しな 


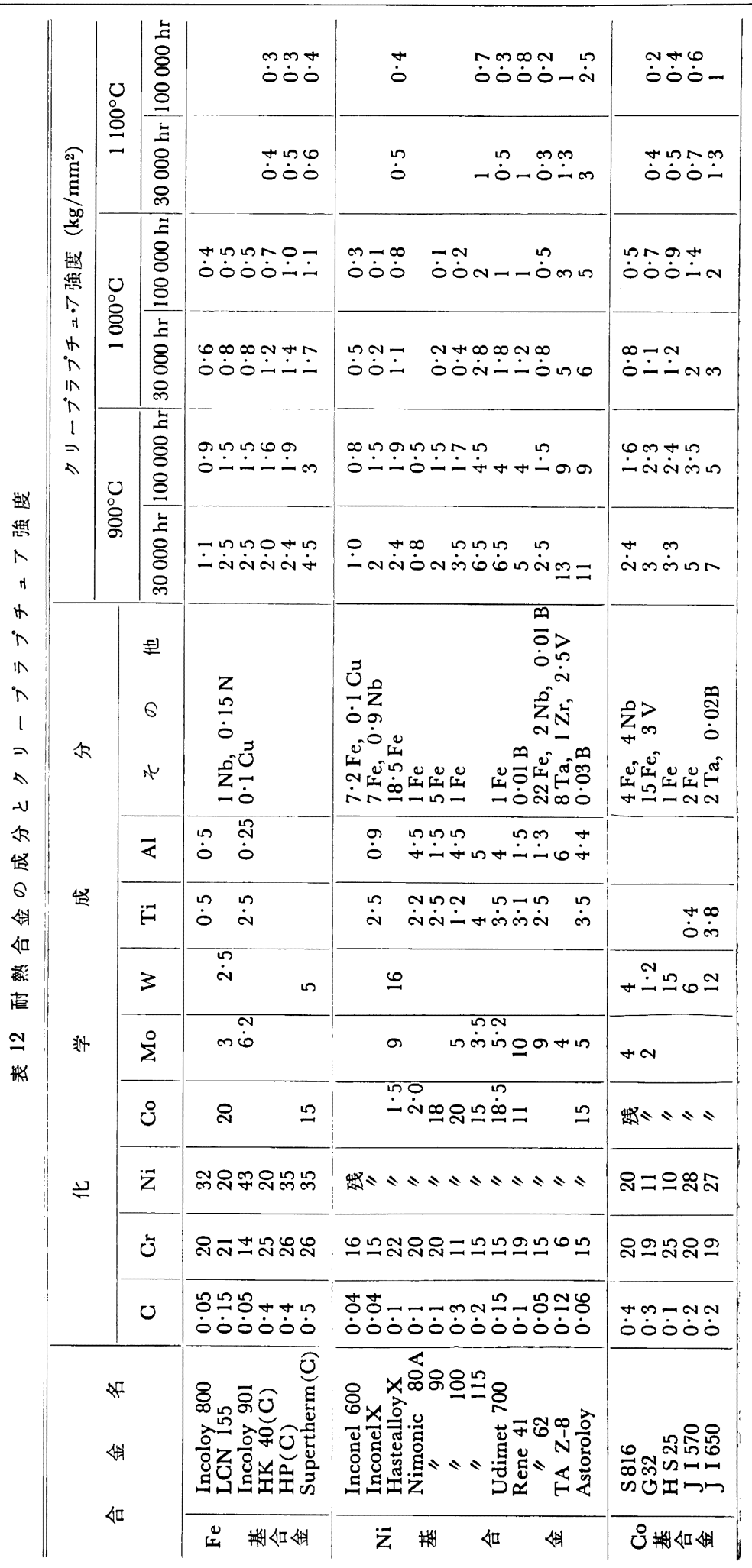


どが検討された。

ついで水素 $10000000 \mathrm{Nm}^{3} /$ try プラントを想定して， 水素製造コスト計算例，および直接還元プロセスと必要 なガス組成の関連について検討が加えられた。

以上の検討に基づき, 各種の原料炭化水素および製造 プロセスに対して水素製造原価を比較するために簡単な 計算方式を設定し，本方式によつて次の各場合に対する 原価の比較を行なつた。

（1）メタンを原料とする場合

（a） LNG 利用酸素製造，部分燃焼

(b) 外部加熱水蒸気改質

（2）ナフサを原料とする場合 外部加熱水蒸気改質

（3）原油を原料とする場合

（a）蒸留，水蒸父改質をふくむオレフイン併産， オフガス，残油の酸素による部分燃焼方式

（b）オレフイン，アセチレン併産

熱媒体加熱プロセス*

酸素使用単一流動層*

高温水蒸気アセチレン併産*

(c) 完全ガス化

酸素使用部分燃焟

熱媒体プロセス*

（4）重油を原料とする場合

(a) 酸素使用部分燃焼

(b) 熱媒体プロセス*

（5）缶残油またはアスファルト

(a) 酸素使用部分燃焼

（b）熱媒体プロセス*

以上の諸方式中, 大規模化に当り今後の開発を必要とす るものには*印を付した.

（6）以上の検討に基ゔき第 5 小委員会は次のような 見解に達した。

1） 7〜10 年後に予測される原子力発電の普及, 石油 化学原料用のナフサ需要抢よび燃料油無硫黄化の必要性 から，原子力熱エネルギーを利用する直接還元のために 大量・安定に供給できる炭化水素資源としては, 液化メ タンおよび重質油（原油, 重油, 減圧缶残油など) が適 する.

2) 原子力製鉄用の還元ガス原料としては唯一のもの に限らず，液化メタンおよび重質油の両者を併用するこ とが，資源産出の経済側的恣威を封ずるために必要であ る.

3) メタン，ナフサを原料とする場合は外部加熱型の 水蒸気改質プロセスが技術的に完成しているが，改質炉 の加熱方式を高温の $\mathrm{He}$ に代替するためには，まず反応 管壁を通しての水素透過の現象が明らかになつた上で設 計および開発研究を進める必要がある. また, 高温 $\mathrm{He}$ の熱エネルギーを炭化水素に与えるために熱媒体，たと
えば水蒸気，鉛などを利用する場合の概念設計を行なう 必要がある。

4 ) 原油, 重油, 減圧缶残油などの重質油は酸素を用 いる部分燃烊によつてガス化されるが，酸素コストのた めに製造原価を小さくすることができない， $1400^{\circ} \mathrm{C}$ 程 度の高温ガスが発生するのでそのまま直接還元反応装置 に送入できる有利性はあるが，これはほとえど硫黄の存 在しない高価な重質油に限られる.

5) 上述の理由により原子力製鉄のプロジェクト進行 に先だつて, 重質油 (原油, 重油, 減圧缶残油など) を 原料とし，酸素を用いることなくガス化・脱硫反応を行 なわせ，乙かも原子力熱エネルギーを大量効果的に利用 しうるプロセスの開発研究を行ならことが肝要である.

各種重質油のうち技術的に最も処理しにくいものは減 圧午残油であるため，これについてのガス化技術を完成 しておけば原油，重油に対してはそのまま容易に適用で きる.

6) 公害予防のため燃料油中の硫黄含有量は低い値に 押える必要性が増加し, 高硫黄含量の減圧缶残油は将来 有力㳊低廉炭化水素源となろう。ガス化反応装置はその まま水添脱硫装置であるから，原油中の硫黄の大半を減 圧残油に集中させ，これを大量に使用して発生する還元 ガスから硫化水素の形で硫黄を吸収除去することができ れば，公害予防と硫黄の資源化が一挙にできることにな る.すなわちコスト高の原因となる重質油からの脱硫プ 口セスを使用する必要がなくなり, 石油資源全体として の無硫黄化を低コストで行ないうることになる.

3.7 .2 昭和 46 年度共同実験

以上の観点から第 5 小委員会としては第一段階として 「重質油からの還元ガス製造プロセスの開発研究」が重 要であるとの結論に達しそれに基づき原子力部会は昭和 46 年度の共同実験上して 12 社（鉄鋼メーカー, 機器製 作メーカー, エンジニアリング会社）参加による還元ガ 又製造に関する実験を準備中である。この共同実験は熱 媒体循環方式に上る重質油（特に減圧缶残油を対象とす る）からの還元ガス製造技術の開発を目指しているもの である.

\section{4. 海外における研究活動}

海外における原子力エネルギーの製鉄工程への利用の 開発研究は, とくに西独において, Aachen 工大, Jülich 研究所を中心にもつとも積極的汇進められている. 米国 では，還元鉄製造・電炉製鋼の方式を，今後高炉一転炉 方式と相補完させるべきものとして，技術開発とその実 用化に意欲的な動きが見られる. 原子力熱エネルギーの 利用は，その次のステップとなろうという見解の模様さ ある.

\subsection{EEC における研究}

EEC では, 1969 年1月, Aachen 工大 Prof. $H$. 
表 13 EEC における原子力製鉄の研究の概要

研究担当 アーヘン工大 総 合 調 整

BBK（西独）原子炉, 発電設備

SOClA (仏) 中開ループ (含熱变)

CSM（伊）メタン還元プロセス, 海綿鉄, 全般設備計画

\begin{tabular}{|c|c|c|}
\hline 項 目 & 還 & 備 \\
\hline $\begin{array}{l}\text { 原子力製鉄 } \\
\text { 基本方式 }\end{array}$ & $\begin{array}{l}\text { 直接製鉄一電炉製鋼方式 } \\
\left(\mathrm{CH}_{4} \text { 改質による流動層 } \mathrm{H}_{2} \text { 還元 }\right)\end{array}$ & \\
\hline 製鉄所規模 & $\begin{array}{l}\text { 溶鋼生産規模 } 360 \text { 万 } \mathrm{t} / \mathrm{y} \text { (日産 } 1 \text { 万 } \mathrm{t} \text { ) } \\
\text { 還元鉄工場, 製工珮工場 (電炉一連続鋳造) } \\
\text { 成品工場 (Strip mil, Plate mill) }\end{array}$ & 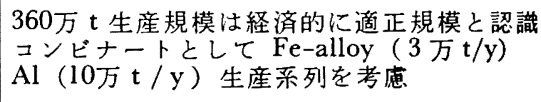 \\
\hline 原子炉関倸 & 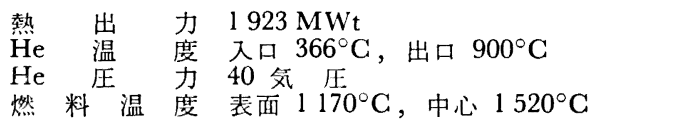 & $\begin{array}{l}\text { PCRV 構造 } \\
\text { 熱交換器等内蔵せ } \\
\text { 稼動時開 } 800 \mathrm{hr} / \mathrm{y} \\
\text { 制 御棒 } 91 \text { 本 }\end{array}$ \\
\hline $\begin{array}{l}\text { エネルギー } \\
\text { 関係ハシシン } \\
\text { ス }\end{array}$ & 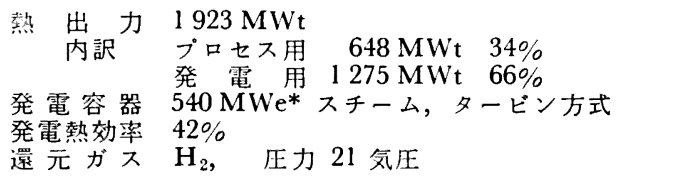 & 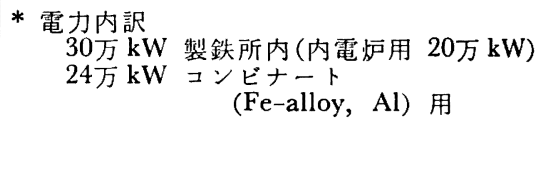 \\
\hline 鉄鉱石還元 & 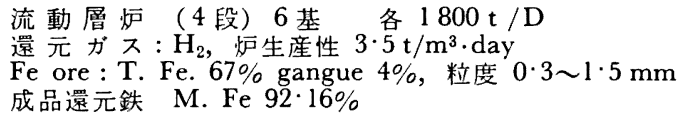 & \\
\hline 電 炉 製 鋼 & 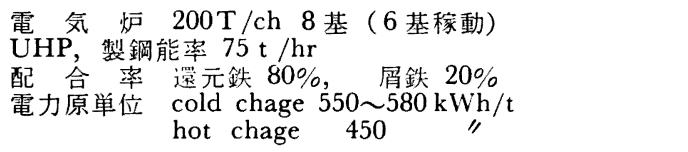 & $\begin{array}{l}\text { 鉱石還元炉と電気炉（各実衝炉）は1基う } \\
\text { つeriesに連結した操業を行なう. }\end{array}$ \\
\hline $\begin{array}{l}\text { 溶鋼製造コ } \\
\text { スト比較 }\end{array}$ & 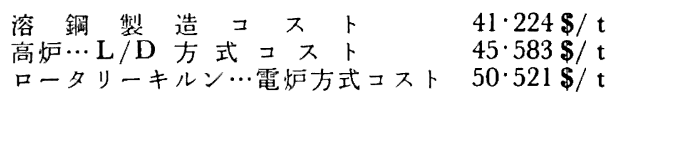 & 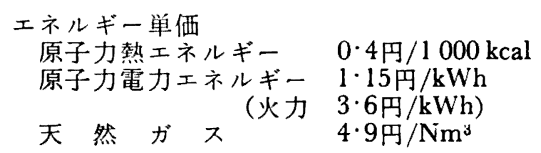 \\
\hline
\end{tabular}

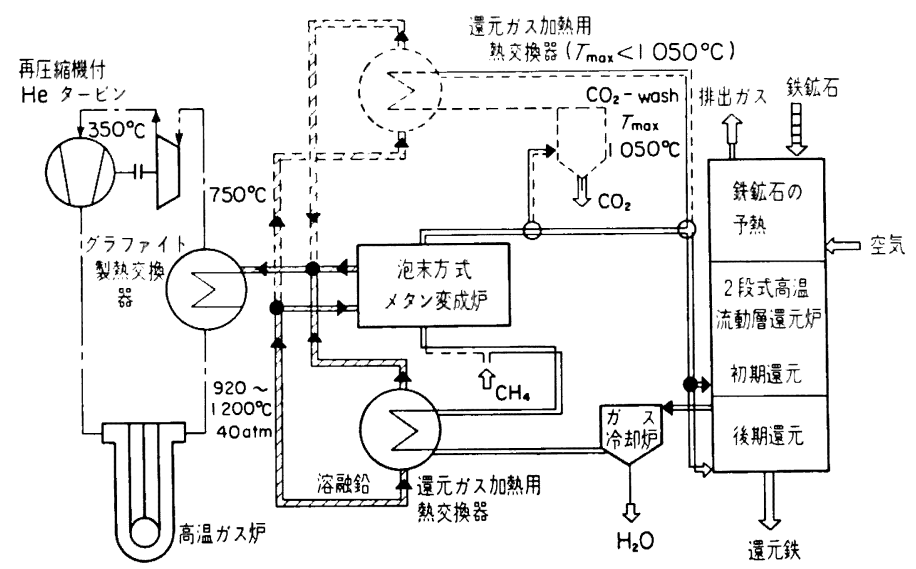

図 6 原子力熱エネルギーを利用してメタンから還元ガスを製造する アーヘンエ大方式製鉄プロセス 


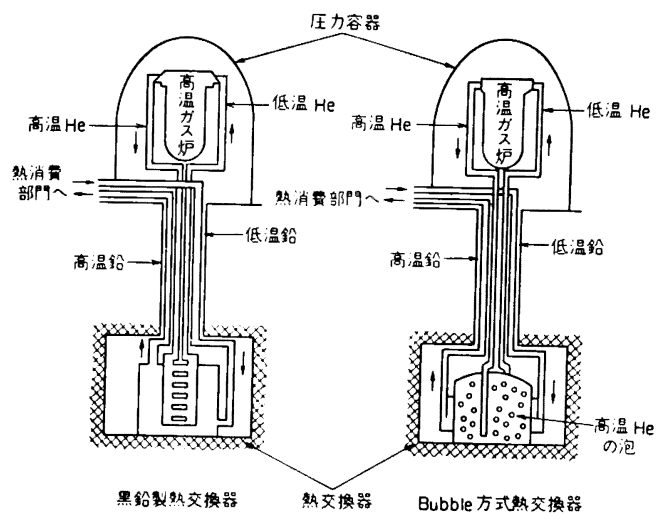

困 7 溶融鉛による熱交換法の表示

表 14 Jülich 原子力研究所の検討による 原子力製鉄プラント

\begin{tabular}{|c|c|}
\hline 生産規模と生産方 & $\begin{array}{l}\text { 粗鋼年産 } 620 \text { 万 } \mathrm{t}, \quad \mathrm{CH}_{4} \text { 源による } \\
\mathrm{H}_{2} \text { 直接還元一電炉製鋼 }\end{array}$ \\
\hline 原子师熱出力 & $3000 \mathrm{MWt}$ \\
\hline $\begin{array}{l}\text { 熱エネルギー利用 } \\
\text { 電気 " } " ~\end{array}$ & $\begin{array}{l}1300 " 43 \% \\
1700 " 57 \% \text { (製鉄所内使用) }\end{array}$ \\
\hline $\mathrm{He}$ ガス温度 & HTGR 出口 $950^{\circ} \mathrm{C}$ \\
\hline 還元および薑元炉 & $\begin{array}{l}\mathrm{H}_{2} \text { ガスー予熱 } 1000^{\circ} \mathrm{C} \\
\text { シャフト坭 }\left(900^{\circ} \mathrm{C}\right)\end{array}$ \\
\hline 製 & 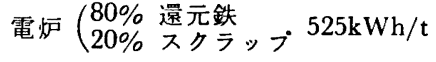 \\
\hline
\end{tabular}

$\mathrm{CH}_{4}$ 分解ガス化のコスト -Jülich（原子力エネルギ一使用の有利性）

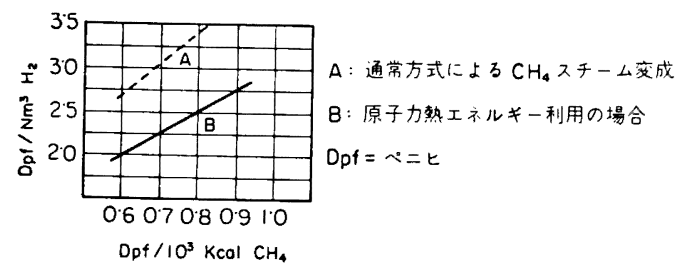

SchencK および Prof. $W$. Wenzel を中心に, EEC 域 内の関係機関の共同により, 年産 360 万 $\mathrm{t}$ 規模の原子力 製鉄一貫体制を想定して，1 年間にわたる研究結果を発 表している.ここでは高温ガス炉を中核に，直接製鉄一 電炉製鋼のプロセスモデルを対象に, 総合一貫的に, 技 術, 設備, コストの全般にわたり検討を加えており, 部 分的にいくつかの問題点を残しているとはいえ, その業 績は高く評価されるべきものである.（表 13 参照） 昨年 9 月東京における 鉄鋼科学技術 国際会議において Prof. $W$. WENZEL はこの EEG パターンを修正発展さ せたひとつのパターンを発表している. 困6に示すこの

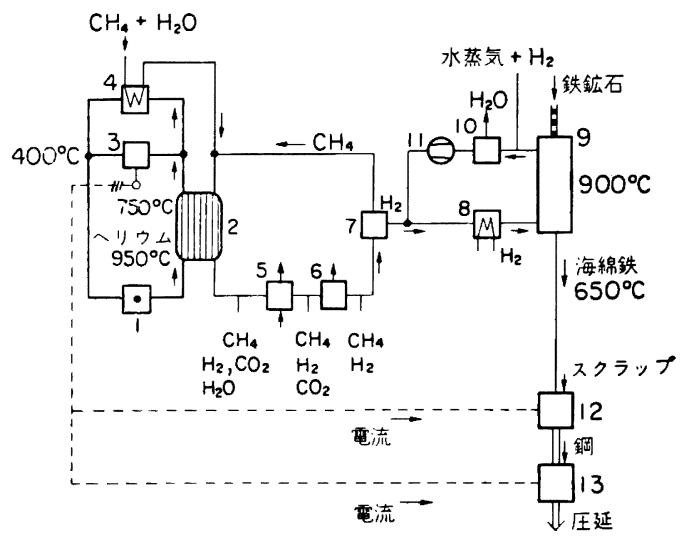

1. 原子如 $(3000 \mathrm{MWt})$

2. 分解反応始 $\mathrm{CH}_{4}+\mathrm{H}_{2} \mathrm{O} \rightarrow \mathrm{CO}+3 \mathrm{H}_{2}-49 \mathrm{kcal} / \mathrm{mol}$

3. ガスタービン貔設 (or スチームタービン)

4. 熱交換器

5. 変換 $\mathrm{CO}+\mathrm{H}_{2} \mathrm{O} \rightarrow \mathrm{CO}_{2}+\mathrm{H}_{2}$

6. $\mathrm{CO}_{2}$ 洗浲

7.メタン分離

8. 水素予報 $20^{\circ} \mathrm{C} \rightarrow 1000^{\circ} \mathrm{C}$

9. 透元妒 $\mathrm{Fe}_{2} \mathrm{O}_{3}+3 \mathrm{H}_{2} \rightarrow 2 \mathrm{Fe}+3 \mathrm{H}_{2} \mathrm{O}-195 \mathrm{kcal} / \mathrm{kg} \mathrm{Fe}$

10. $\mathrm{H}_{2} \mathrm{O}$ 凝縮

11. $\mathrm{H}_{2}$ 圧縮㙨

12. 製鋾

図 8 Jülich 原子力研究所により検討された 原子力製鉄ブラントフローシート

提案は，中間熱媒体として溶融鉛を採用，とくに溶融鉛 槽中における He ガスのバブリング (babbling) により 隔壁を不要とする熱交換方式の開発の有意義性を強調し ている（図7)。

\subsection{Jülich 研究所における研究}

Jülich 研究所では上述の EEC の研究とは別個に, 粗 鋼年産 620 万 $\mathrm{t}$ 規模の原子力製鉄プラントの経済性評価 を行なつている. 表 14 および図 8 に示すごとく，直接 還元一電炉方式のモデルを対象とし, 現行高炉一転炉プ ロセスとの経済性の比較を行ない，原子力製鉄の有利性 と，とくに原子力熱エネルギーを利用しての還元ガス製 造のメリットを強調している.

\section{5. 結}

語

以上原子力製鉄の技術開発に関し，問題意識，フィ口 ソフィといつたものについて冒頭考察し，ついで鉄鋼協 会原子力部会における共同研究検討の経過を中心に説明 を加えてきた：ここに結語として当面する問題を要約 し，今後の開発の進め方について所見の一端を述べる.

（1）原子力エネルギー導入を顧慮すべき必然性一エ ネルギー最多消費部門である製鉄業として，原料炭以下 の現行エネルギー需給と使用実態面に，公害環境対策の 課題も加わり問題が深刻化しエスカレートしつつあるさ 中に登場した新エネルギー源としての原子力エネルギー 利用の技術的方途を研究すべきことは当然である. 殊に 
エネルギーの全般にわたり他国に比し格段に劣悪条件中 におかれているわが国として，その必然性は最も大き い. 原料炭の問題など現実局面の变転に一喜一喜する態 度でなく, さらに高い次元, 広い観点から行なうべき開 発テーマであることを十分に理解することが肝要であ る.

（2）技術開発の特質と要望される体制一前述したよ うに最終的な原子力製鉄の標準方式と目される直接還 元, 電炉製鋼方式は, 原子力エネルギーの積極的導入に は適しているとはいえ, 現状では高炬一転炉の主流方式 に比較し, 生産性, コスト面で全く太刀討ちしがたい条 件下にある. 原料炭のコストアップなど, 直接還元を相 対的に有利にする要素はあるが，これに安価豊富を期待 される原子力エネルギー（熱および電力）のバックアッ プが加わり, どの程度の比較競争力を持ちうるものかは 今後の検討に待たねばならない，また生産設備単位の大 型化, 能率化汶対しては抜本的な開発が実現されること が肝要である. 前述のように, 開発の対象と局面の多様 性と広汎にわたることから，組織的で効萆のよい開発体 制と運営がはかられねばならない。

（3）高温ガス実験炉の意義一原子炉々型として $\mathrm{He}$ ガス冷却高温ガス炉方式が適格であり，他国とエネルギ 一事情を異にするわが国として，この炉型の開発に対し 独自の推進を図るべきものである. He ガスの, それぞ れ高温, 中温, 低温域を製鉄プロセス, 発電, 化学工 業, 一般蒸気や海水淡水化など，いわゆる多目的利用を 実現すれば，原子力エネルギー利用の総合的経済性をい ちじるしく高めることが可能である.この観点から, 日 本原子力研究所で計画中の 5 万 KWt の実験炉は, 原子 炉々型の技術開発と多目的利用技術開発の両面から，極
力早期に寒現されるよう強く要望するものである.この 実験炉段階を目途として，原子力製鉄の技術開発の道は 大きく拓かれることと期待するものである.

（4）原子力製鉄実現に至る道程の研究の必要性一前 述した原子力製鉄標準プロセスの実現, さらには高温ガ ス炉を中核とする多目的コンビナート形態などは，いわ ば最終的ビションであり，現実問題としては，乙れへの 移行段階における中間体系のあり方，あるいに現行製鉄 方式の枠中における原子力エネルギー導入と調和の可能 性の追及などについて真剣に研究を行なうことが必要で ある、このような現実措置は，原子力エネルギーの利用 の突破口を拓くべきものであり，最終的なビショョン実現 のアプローチを，より現実的ならしめるものであろう. またここで強調しておきたいことは，原子力製鉄の技術 開発への挑戦を通じて, 副次的に, 現状技術水準を破る 諸種の革新的と称すべき技術開発の成果が期待されうる という点である. 新製鉄技術方式の開発, 超高温材料の 開発, 産業界の発展に共通儿貢献する新熱交換方式, 新 しい還元ガス製造技術の展開など, 開発と応用の可能性 は極めて広沉である. 特殊鋼電炉メーカーを主とする主 原料対策としての還元鉄技術の推進の意義も大きいと見 られる。

（5）以上のごとく原子カエネルギー利用の技術開発 は，単に鉄鋼業の範囲内にとどまらず，ひろく将来の産 業構造の問題に関連するところが大きい，また開発規模 が大きく，多方面にわたること，多額の開発資金を要す ることから考元，鉄鋼業としては，関係機関，関連産業 分野との密接な協力関係のもとに, 効密的総合開発の推 進をつよく要望してやまないものである. 